AA RAWINGS, MINIATURES, STATUETTES

BUSTS, SNUFF BOXES

BONBONNIËRES, MEDALLIONS, MEDALS

AND OTHER OBJECTS OF ART

relating to
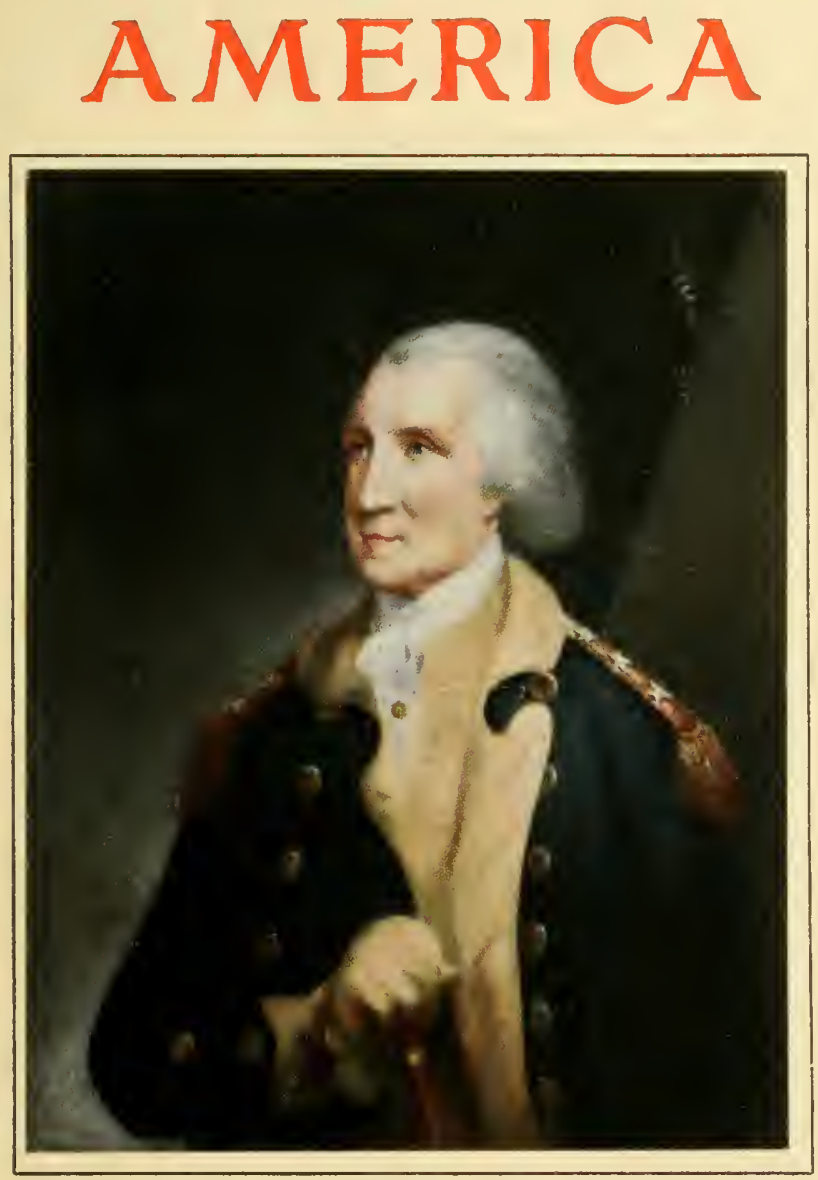

General George IVashington

(No. 56)

On sale by

GODEFROY MAYER

Dealer in old prints

41, Rue Blanche, 41

PARIS 


\section{LIST OF CONTENTS}

Nos.

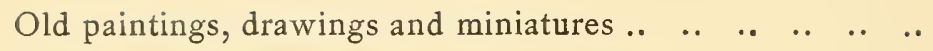

Old busts and statuettes

II 4 - I79

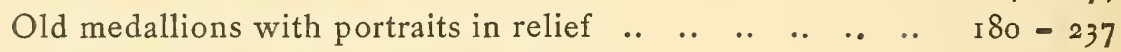

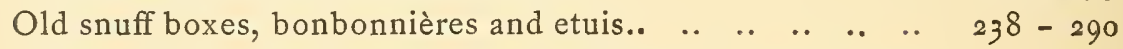

Old enamels, clocks, watches, letter weights, cups, plates,

seals and other objects of art ..

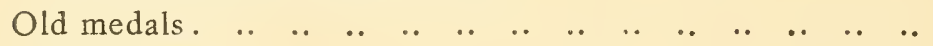

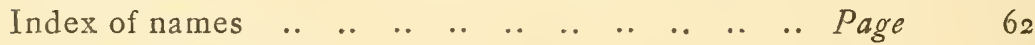

Topographical index ..

Index to painters, draughtsmen and sculptors .. $. . \quad-\quad 64$

General index..

No less than thirty years have been devoted to the formation of the collection now described, and offered for the first time in separate lots at fixed prices. Most of the items were acquired in Paris, but several important purchases were made in England, Germany and Italy. Many of the choicest objects come from such notable collections as those of Morel de Vindé, King Louis Philippe (from La Muette and Eu Castles), Talleyrand (from Valençay Castle), King Charles Albert of Sardaign (from Govone Castle), Lord Bessborough, Lapeyrie, Mr. Hammer of Stockholm, Benjamin West, Destailleur, Baron Pichon and others.

\section{This catalogue is the first of a series of four all exclusively of American interest, viz :}

Catalogue No 30. The present catalogue.

$-\quad$ 31. Historical engravings and political caricatures.
- 32. Old engraved portraits of famous personages
- $\quad$ connected with the history of America.

Each of the above mentioned catalogues is illustrated with numerous facsimiles, and each ends with four indexes, viz: an index of names, a topographical index, an index of painters, sculptors and engravers, and an index of general subjects.

Any of these catalogues are sent gratis and postfree on application.

\section{POSTAGE TO FRANCE : \\ 5 cents for letters and 2 cents for postcards}

Since r 909 , old engravings, paintings and works of art enter the U. S. A. free of duty. 


\title{
OIL PAINTINGS
}

\section{DRAWINGS, WATER - COLOURS,}

\author{
PASTELS AND MINIAT,URES
}

OF

\section{AMERICAN HISTORICAL IMPORTANCE}

\author{
ADAM (Victor) \\ French painter and designer (1802-1867)
}

I Portrait of General Lafayette, on horseback, IS30. Beautiful pencil-drawing. Signed. I 2 I/4 by $9 \mathrm{I} / 2$ inches.

Fr. $400-$

\section{AUBRY (Louis-François)}

French miniature painter

2 Portrait of Benjamin Franklin. He is represented full bust, directed to left, head slightly to right. Oval. Signed. 3 by 212 inches.

Fr. 5.000

Beautiful miniature of the most delicate execution. Louis François Aubry, a pupil of Isabey, was born in Paris in 1770 , and was a clever portrait painter who occasionally painted miniatures. An example of his work representing the Princess Pauline Borghese, sister of Napoleon I. can be seen at Hertord House. He exhibited two portraits of the King and Queen of IVestphalia at the Salon in ISro. In a Paris sale, about six years ago, i. e. before the enormeous rise in the prices of the old works of art, a small miniature of Queen Caroline of Naples was sold for 5346 Francs.

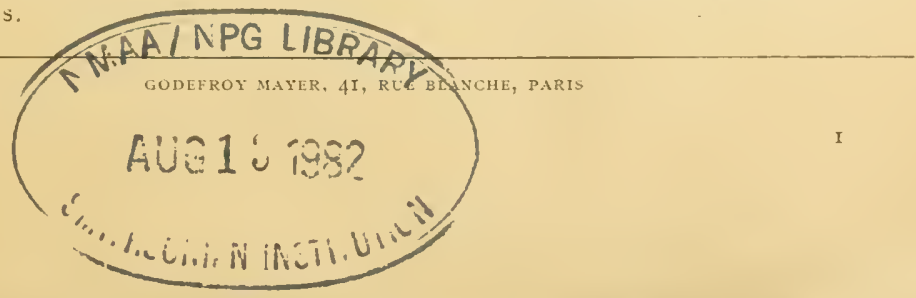


ARMAND DUMARESQ (Charles-Edouard-Armand, called) French painter, pupil of Couture (1826-1895)

3 Portrait of General Arnold. Chalk drawing. I 3 by 9 1/2 inches.

Fr. $150-$

4 Portrait of Benjamin Franklin. $\mathrm{He}$ is represented full bust, directed to right. Beautiful black and white chalk drawing on blue paper. Signed and dated, 1870. I5 I/2 by 13 inches. Fr. $300-$

5 Portrait of General Washington. Life size head. Beautiful charcoal drawing in black and white. $203 / 4$ by $43 / 4$ inches.

Fr. $300-$

6 George Washington and eight members of the Congress sitting round a table. Washington making a speech and proposing a toast. Beautiful chalk drawing. Signed. $123 / 4$ by $19 \mathrm{I} / 4$ inches. Fr. $200-$

7 George Washington resigning his fonctions as general, March 15 th 1783 . Charming pen and ink drawing. $6 \mathrm{I} / 2$ by 9 inches.

Fr. I 50 -

8 Last interview of Washington with his officers, December 4 th 1783. Charming pen and ink drawing. $6 \mathrm{I} / 2$ by 9 inches.

F1. $150-$

9-The sword of Washington. - Washington's arms. The decoration of the Cincinnatus. Two fine water colour drawings. 9 I/4 by $63 / 4$ inches.

The pair Fr. 50 -

Io Proclamation of the independence, Philadelphia, 1776. Beautiful original pencil sketch for his painting ordered by the Congress. IO I/4 by I 7 I/4 inches. Fr. $200-$

I I Comte de Deux-Ponts, Duc de Laval-Montmorency and Comte de Custine at Yorktown, 1781. Beautiful water colour drawing. Gilt frame. 9 by 12 inches.

Fr. $200-$

I 2 Sketch for the battle of Lexington. Charming pen and ink drawing. 9 by $63 / 4$ inches.

Fr. 75 -

I3 Bouille at Bristomhill; January 11 th 1782. Pencil sketch, with another sketch on the reverse side. $6 \mathrm{I} / 2$ by 9 inches.

Fr. $100-$ 
I4 Taking of Tobago by the French, commanded by Bouillé. Charming pen and ink sketch. 9 by $63 / 4$ inches.

\section{AUVREST}

Master of drawing to the court of Louis XVI.

I5 "Vincet Libertatis Amor". The Marquis of La Fayette between the genii of War and Victory. Beautiful allegorical drawing, 1790. Signed and dated. With four lines of poetry by Captain d'Ussere. I2 I/a by IS $3 / 4$ inches.

Fr. Soo -

Previous to the Revolution Auvrest bore the title of "Dessinateur de Mesdames", the daughters of Louis XV. His speciality were calligraphical drawings in which art he excelled. His portraits of Napoleon, La Fayette and other personages were all drawn from life and are much appreciated for their perfect likeness.

16 Photographic facsimile, reduced. Fr. $2-$

\section{BAUGEAN (After)}

Naval designer

17 The U. S. frigate "The President". - Capture of the English brick "Carnation", Oct 3 d. 1808. - Capture of the "Marengo", etc. Four clever sepia drawings on two sheets, one on each side. 8 by ro $1 / 2$ inches.

The lot, Fr. 25

\section{BERNARD}

Calligraphical designer to the court of Louis XVI.

IS "Franklin. Eripuit fulmen cœlo sceptrum que tyrannis". Calligraphical portrait of Benjamin Franklin. He is represented full bust, in profile to left within calligraphical and ornamental frame. About 17So. 1634 by 12 I 2 inches.

Fr. 1800

This portrait is entirely different to all the other types known, and it has been drawn between $177^{8}$ and 1780 , when the artist was "Professeur et dessinateur des pages du Roi et de Mlesdames Royales ". He executed the portraits of the King, the Queen and of all the famous personages of the court of Louis XVI., and during the first phase of the Revolution those of Mirabeau, Madame Roland, Voltaire, Rousseau, etc. All this portraits were taken from life and are considered tho truest likeness existing.

I9 Photographic facsimile, reduced. Fr. 2 


\section{BROWN (John Lewis)}

French painter. Born in Bordeaux (I829-1890)

20 Rochambeau in America. Beautiful pen and ink drawing. Signed. 9 I 4 by 13 I 2 inches. Fr. $250-$

\section{CLARY, 18,8}

Miniature Painter

2I Miniature portrait of General La Fayette. $\mathrm{He}$ is represented nearly to waist, in civilian dress, directed to right. On ivory. 5 by 4 r 4 inches. In velvet frame, gilt rimmed.

Fr. I $500-$

This miniature is of the finest workmanship and certainly the truest likeness at the time of General La Fayette. It is signed to left "Clary, 1818 ", which is probably the pseudonym of a skilful miniature painter, whose real name however could not be ascertained.

\section{COLLET (John)}

British painter and designer (1725-1 780$)$

22 Portrait of Richard, Earl Howe, celebrated English admiral, joint commissioner with his brother William for restoring peace with the American Colonies. He is represented three-quarter-length, in uniform, cocked hat, cannon to right. Beautiful sepia drawing. 123/4 by 10 I' 2 inches.

\section{COUDER (Louis Charles Auguste)}

French painter. Pupil of Regnault (I790-1 $S_{73}$ )

23 Battle of Yorktown, Generals Rochambeau and Washington giving the last orders for the attack. Sketch for the large picture in the "Galerie des Batailles" of the "Palais de Versailles". Oil painting on cardboard. I 2 1/4 by 9 inches. Contemporaneous gilt frame.

This subject had beeı engraved by Fontaine.

24 Battle of Yorktown. Rough sketch for the previous picture. Oil painting on card board. I I $3 / 4$ by 8 I $/ 2$ inches. Gilt frame. Fr. $150-$ 


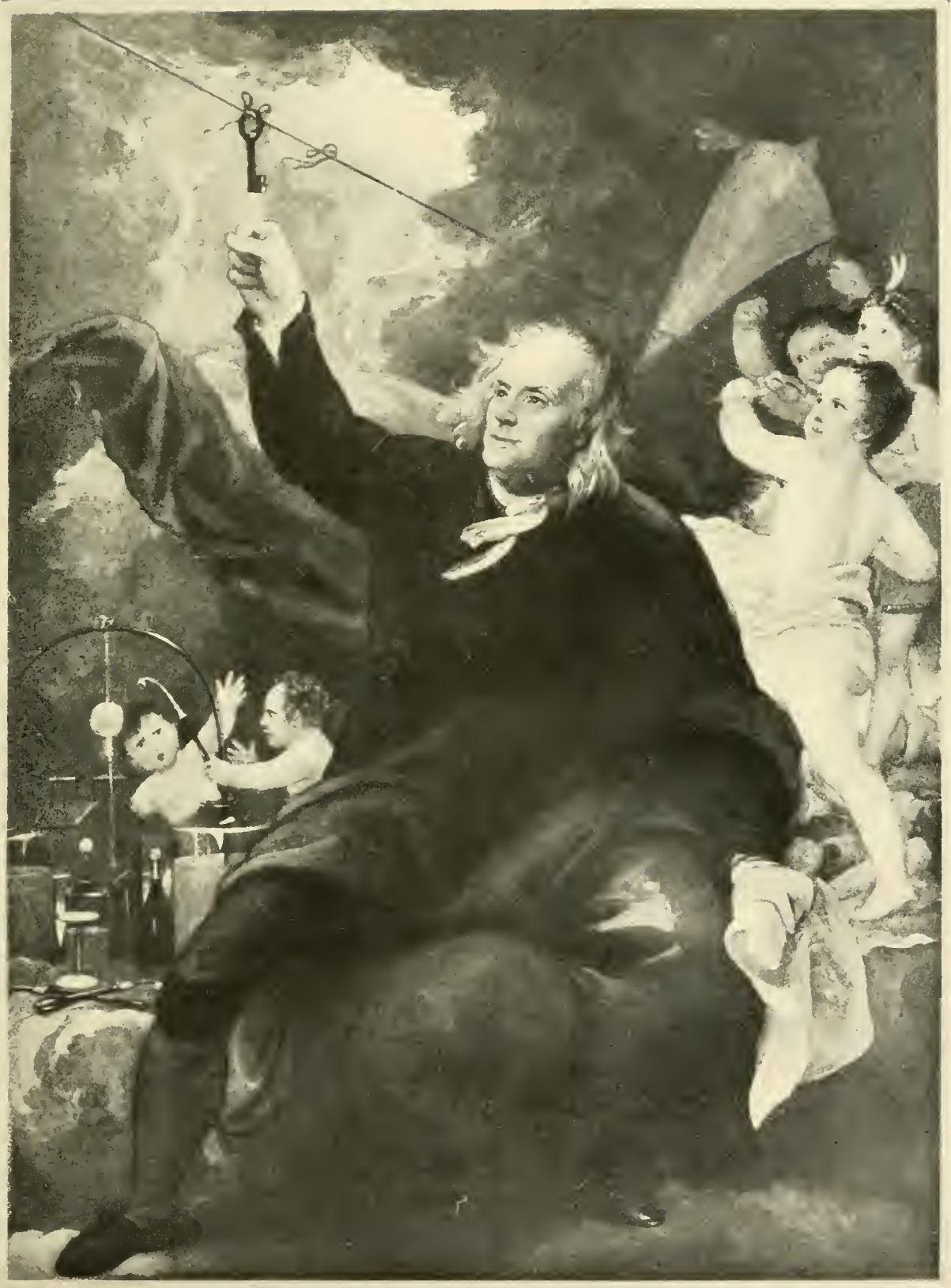

Benjamin Frankein.

See No. $\mathrm{S}_{3}$. 


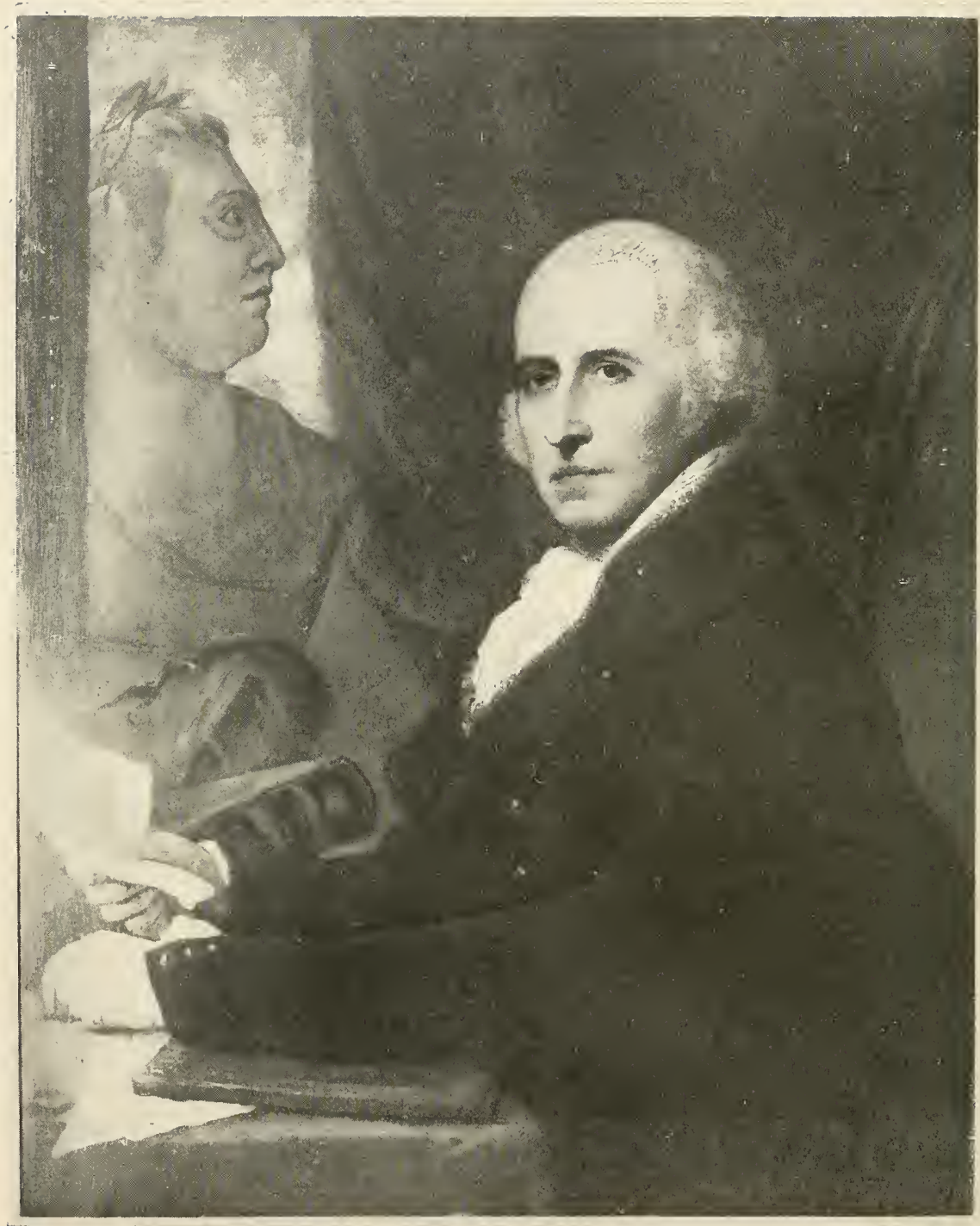

Benjamin 'West.

See No. 39. 


\section{DANLOUX (Pierre)}

Celebrated French portrait painter (1753-1809)

25 Portrait of Bertrand François Mahé de La Bourdonnais, celebrated French naval officer and governor of the French possessions in India. $\mathrm{He}$ is represented full length in naval uniform. Signed and dated, i777. Old gilt frame.

Fr. 1500

\section{DEBARZ (A.) 1747}

26 "Carte générale de toute la Côte de la Louisiane jusqu'à la Baye Saint-Bernard". Curious old map in water-colours. I3 I 4 by 16 I 2 inches. Fr. $25-$

\section{DROUOT (E.) 1839}

27 Portrait of Benjamin Franklin. Life size head after the bust by Houdon. Beautiful lifelike drawing. Signed and dated. 20 by 1034 inches.

Fr. $100-$

\section{DUPLESSIS (After)}

28 Portrait of Benjamin Franklin. Old oil sketch on card board after the painting by Duplessis. He is represented full bust, directed to front, with flowing hair. Oval. About i7so. I 4 by I inches. Fr. $150-$

\section{DUPLESSIS-BERTAUX (Jean)}

Painter, designer and engraver (1747-1S19)

29 Portrait of General I:a Fayette. Full bust, in uniform, profile to left. Beautiful circular miniature in sepia. Signed. Ebony frame, gilt rimmed. Diameter, 378 inches.

Fr. $500-$

\section{ESTNER (S.)}

30 Portrait of General La Fayette. Full bust, in the uniform of commander of the Garde Nationale, profile to right in an oval, surrounded by laurel branches. Oil painting on wood. About I790. Signed. Old gilt carved frame, 5 I 2 by 334 inches. Fr. $150-$ 


\title{
GERARD (Mademoiselle Marguerite)
}

Lady engraver and designer, sister-in-law and pupil of Fragonard (1762-1825)

31 "Au Génie de Franklin". Large allegorical composition, very probably the model drawing from which Fragonard etched and Miss Gerard finished the wellknown engraving of Franklin. 21 by 15 I/2 inches. Fr. $600-$

\author{
G]RARDET (Edouard) \\ Swiss painter and designer. I 9 th century
}

32 Whole length portrait of General Washington. Beautiful pencil drawing. $33 / 4$ by $63 / 8$ inches. Fr. $250-$ With the engraving by Wolff executed after this drawing

\section{GRAINCOURT (Antoine N.B.)}

French painter and designer (1748-1823)

33 Ten portraits of celebrated French admirals and naval officers of the 17 th and 18 th centuries all of interest to American history. Beautiful oval pencil drawings. $4 \mathrm{I} / 8$ by $3 \mathrm{I} / 2$ inches. Each Fr. $150-$

Jean Bart - Duke of Beaufort - Dreux Brézé - Duguay Trouin Duquesne - La Galissonnière, Governor of Canada - La Roche Saint André - L'Etanduère - Mahé de La Bourdonnais - Valbelle.

All the above have been engraved by Hubert in $\mathrm{I} 7 \delta_{\mathrm{I}}$ and an impression of each is added to the above drawing.

\section{GRIBELIN (E. A.)}

34 Sketches for the portrait and the medal struck in honour of Admiral Suffren. Four beautiful circular sepia and pencil drawings. Signed: "Croquis que j'ai fait d'après M. de Suffren pour la médaille de Provence."

With the original etching executed by Gribelin himself.

Fr. 175 -

\section{JELGERHUIS (Jean)}

Dutch painter $(1760-1836)$

35 Portrait of Comte de Grasse, the French admiral, chiefcommander in the American war. He is represented full length, in naval uniform, seated, right hand resting on table upon which is a map inscribed "Amerika". Beautiful pastel. Signed. 12 by $9-3 / 4$ inches. I 8 th Century gilt frame entirely carved.

Fr. $600-$ 
LACOUR (Pierre)

Painter and designer. Director of the Academy of Bordeaux (1745-1814)

36 Triomphal arrival of Admiral Comte d'Estaing and of his flag ship "Languedoc" in the port of Brest. Beautiful allegorical pencil drawing. Signed. 17 i 4 by 24 inches.

Fr. $800-$

This interesting drawing was engraved twice, $1^{\circ}$ by Lacour himself, $2^{\circ}$ by an unknown engraver, probably Guttenberg. The drawing was ordered for a festival given by the Chamber of commerce in Bordeaux, January 6 th, 1780 , in commemoration of the French victories in America.

\section{LE BARBIER AINÉ (Jean-Jacques-François)}

French painter and designer $(1738-1826)$

37 Portrait of John Hancock, President of the American Congress. He is represented half length, directed towards left, medaliion within rectangle, cap of liberty to right, cannon below. Beautiful sepia drawing. Signed. 6 i $/ 8$ by $37 / 8$ inches.

Fr. $300-$

This portrait was engraved by J. Pelicier in $17 \delta_{2}$.

\section{LE CHEVALIER (Jean-Baptiste)}

Le Hivre. Eigteenth century

38 Le 19 Mai 1780, sur les trois heures après-midi vingt lieues à l'est de la Martinique, le troisième Combat depuis un mois entre l'Armée Française composée de 22 vaisseaux de ligne sous les ordres du Général Comte de Guichen et l'Armée anglaise commandée par l'Amiral Rodney. Representing the naval battle between the French fleet and the English off Martinique. Beautiful water colour-drawing. 28 by 20 inches.

F1. $300-$

J. B. Le Cheralier was an officier and draughtsman of the French Fleet, and this interesting drawing bears the notice. "L'Auteur y étoit acteur". (The artist was himself engaged in this battle).

\section{LESLIE (Charles-Robert)}

Anerican painter (1794-1854)

39 Portrait of Benjamin West. P. R. A. He is represented half length, seated, directed to left, holding paper; in the background a curtain and a bust of George III. Oil 
painting on wood. 36 by $283 / 4$ inches. Valuable old gilt carved frame.

Fr. $10.000-$

From the collection of Benjamin West himself, in whose family this picture remained ever since the artist's death.

Ch. R. Leslie's talents and the taste with which he executed them, have placed him in the foremost rank of American artists. His father Robert Leslie and his mother Lydia Baker, were both Americans and the artist was born in London during a visit of his parents to England. This portrait seems to have been painted about 1816 and probably presented to Benjamin West who was Leslie's master, compatriot and friend.

See illustration.

\section{MAGNIADAS (Franky)}

4I Original sketch for the celebrated Lincoln medal struck in Geneva in 1865. Beautiful circular pen drawing. Diameter 3 I $/ 8$ inches. Fr. $60-$

The medal itself, described under $\mathrm{N}^{\circ} 39 \mathrm{I}$, has become extremely rare and only a ferv specimens are known.

\section{MARTINET}

French engraver and designer of the 18 th century

42 "Le Docteur Franklin". Franklin is represented seated before a table, holding a pen in his right hand. Behind him is the representation of a thunderstorm and lightening in the act of striking a lightening conductor, his invention. Beautiful sepia drawing, probably the model for Martinet's engraving. $6 \mathrm{I} / 2$ by $4 \mathrm{I} / 4$ inches.

Fr. $150-$

\section{MASSARD (L.)}

French designer. I9 th century

43 Portrait of General Rochambeau. He is represented whole-length in military uniform, behind him to right a roll inscribed "Yorktown". Beautiful original pencil drawing. 8 by $5 \mathrm{r} / 4$ inches. Fr. $125-$

The above had been engraved by Gavard for the Galerie de Versailles Collection.

44 Portrait of John Jay, Member of the American Congress. Full bust to right. Beautiful original pencil drawing. 5 by 4 inches. Fr. $100-$

With an impression of the engraving, executed by Gavard after the above. 
45 Portrait of Duguay-Trouin, French naval commander under Louis XIV, Conqueror of Rio de Janeiro. Half length, head to left. $4 \mathrm{I} / 2$ by $3 \mathrm{I} / 4$ inches. Fr. $75-$ This portrait has been engraved by Gavard.

\section{MILBERT (Jacques-Gérard)}

French naturalist, designer and lithographer (1766-1840)

46 View of the village of Sandy-Hill, 210 miles N. of NewYork. Pretty sepia drawing. $33 / 4$ by $53 / 4$ inches.

\section{MONOGRAM H. G.}

47 "A Lafayette. La France libre et reconnaissante lui a élevé ce monument de la liberté, l'an IV (1796)". Beautiful water colour-drawing, representing the plan of a monument in honour of General La Fayette, intented to be erected on the Esplanade des Invalides in Paris. 2I 12 by 153.4 inches.

Fr. I 50

\section{OZANNE (Nicolas-Marie)}

Naval designer (172S-18II)

48 "Terrible situation de Christophe Colomb à l'âge de seize ans". Perilous situation of Chistopher Columbus at the age of sixteen, representing him shipwrecked, clinging to a beam. Beautiful sepia drawing. 6 by I I inches.

Fr. 200

49 "Combat du Héros de 74 canons commandé par Monsieur Beaussier, Capitaine de vaisseau, contre les vaisseaux anglois le Northingham." Representing the engagement of the Heros and the Sirene with three English frigates, off Isle Royale (Nova Scotia), August 27th 1757. Beautiful pen and ink drawing. I 6 by II $1 / 4$ inches.

Fr. 250

\section{PALLJĖRE (Etienne),}

\section{CALLED THE CHEVALIER PALLIĖRE}

Painter and designer in Bordeaux. I $S$ th century

50 "Washington, Libérateur de sa patrie." Beautiful allegorical chalk-drawing in commemoration of the 
death of Washington. Signed. IS by 2 II/2 inches. Fr. $1.200-$

Representing in the centre a catafalque with the above inscription; Washington in the form of a young warrior is being taken up to Heaven by the goddess of Victory; to left are an Indian chief and a female figure (Fate), cutting the thread of life ; to the right, Mars.

5 I "L'Indépendance de l'Amérique reconnue." To the left under a baldachin a female figure representing America ; beside her the idealized portraits of Washington and Franklin; in the foreground are Rochambeau and Estaing in the dress of Roman warriors, the latter pointing to a vessel: Beautiful sepia drawing. $26 \mathrm{I} / 2$ by 20 inches. Modern carved gilt frame. Fr. 2.50052 Photographic facsimile. Fr. 2. -

53 "L'Amérique soutenue par la France." Large sepia drawing referring to the French victories in America. Louis XVI as a young hero having at his side the goddesses of war and Victory, giving audience to General Rochambeau in the dress of a Roman warrior, who presents him with the British escutcheon and the flags conquered from the latter. $26 \mathrm{I} / 2$ by 20 inches. Modern carved gilt frame.

Fr. $1.500-$

54 "Franklin obtient de Louis XVI l'envoi d'une armée pour secourir les Etats-Unis d'Amérique." Representing Benjamin Franklin, Louis XVI, Estaing Rochambeau and other personages near a shore, French frigates to right, a burning city (New-York?) to the extreme left. Interesting water colour-drawing. 2I by $15 \mathrm{I} / 2$ inches. 18 th century carved gilt frame. Fr. 2.000-

This drawing had been engraved in stipple by a Bordeaux engraver, about 1780 .

55 Photographic facsinile. Fr. 2. -

\section{PINE (Robert-Edge)}

English painter of portraits $(1740-1788)$

56 Portrait of General Washington. He is represented half-length, in uniform, head three quarters to left, right hand resting on a walking-stick; in the background to right a flag of which only the pole is percep- 
table. Oil painting. Old carved gilt frame. 34 by 27 inches.

Fr. $45.000-$

Robert Edge Pine, son of John Pine, engraver, was born in London in 1742. He came to America in $178 ;$ for the purpose of painting portraits of the heros and patriots of the Revolution and he made his residence in Philadelphia, having: brouglit letters of introduction to the Hon. Francis Hopkinson whose portrait was the first he painted in that country. It was the letter of that gentleman to Washington, explaining Pine's design of collecting portraits for historical pictures, and requesting him to sit to the artist, which drew out the celebrated letter, dated Mount Vernon, 16 th May 1785 : "In for a penny, in for a pound, is an old adage..." Pine remained three weeks at IIt Vernon, and besides that of Washington, painted also the portraits of Mrs. Washington's Grandchildren. He died at Philadelphia, November 19, 1788.

57 The same. Reproduction in colours. Published in 1902. 1634 by 13 I 4 inches. Only roo copies have been printed.

Fr. $100-$

\section{PILKINTON (Robert)}

Lieutenant Royal Engineers. I 8 th century

$57^{\mathrm{A}}$ Collection of 9 beautiful water colour drawings and 8 pen and ink drawings representing the Niagara Falls and its surroundings, Fort Oswego, Fort Erie, etc, These drawings are all of different sizes, several very large (IO $3 / 4$ by 42 inches etc.) The lot, Fr. $550-$

One of these drawings is signed on the back, "Robert Pilkington, Lieut. Royal Engineers, Niagara, 16 th Oct. $1796 . "$

\section{POTIER}

Former Captain of infantry, Engineer Adjutant to Narshal de Saxe, afterwards in the service of the Duc d'Orléans. 18 th century

\section{Collection of 7 beautiful water colour-drawings repre- senting forts in St-Domingue (Haiti). I $756-175 \mathrm{~S}$.}

The lot, Fr. 500 -

These drawings are the original work of Captain Potier, the constructor of these forts and are of the highest historical and military interest, especially on the slavery question, as each drawing represents the barbarous punishments to which the negros were submitted. The following are the titles in French :

$1^{\circ}$ Vue de la Redoute St-Louis à l'entrée de la baye de Bayaha. (1 1 I/4 by $17 \mathrm{I} / 4$ inches).

$2^{\circ}$ Vue intérieure du petit fort du Port de Paix que j'ay fini. (10 I/4 by $631 / 2$. inches).

$3^{\circ}$ Vue de la rade du Port de Paix, avec le vieux et nouréau fort. $(9$ by 45 inches). 


\section{8 inches).}

$4^{\circ}$ Vue de la ville du Port de Paix, avec l'ancien et nouveau fort. $(81 / 2$ by

$5^{\circ}$ Vue du grand fort du Port de Paix, prise d'une de mes fenêtres et la vue d'une partie de l'isle de la Tortue. ( $83 / 4$ by 5 I $1 / 2$ inches).

$6^{\circ}$ Vue d'une habitation dans la Sucrerie de la Souffrière et la baye de Moustique. ( 8 I/4 by $48 \mathrm{I} / 4$ inches).

$7^{\circ}$ Vue d'une habitation en sucre fait à Limonade en 1757, Isle St-Domingue. ( 8 I/ 4 by 77 inches).

\section{QUENEDEY (Edme)}

Frèch Physionotrace engraver and designer of portraits (1756-1830)

59 Portrait of La Fayette. Full bust in profile to right. Beautiful circular drawing in black and white. About I 789. Diameter, 4 inches.

Fr. $300-$

\section{ROBERT FLEURY}

French historical painter. 19 th century

60 Christopher Columbus submitting his plans to the Doges of Genova. Oil sketch on card board. Framed. I $23 / 4$ by 9 I 4 inches.

Fr. I 50 -

\section{ROGERS (Nathaniel)}

Miniature painter in New-York

6I Portrait of a young man. Beautiful miniature on ivory. 3 I'8 by $25 / 8$ inches. Ebony frame. Fr. $600-$

On the back of the frame is the card of "N. Rogers, Miniature Painter, N. 154 Broad Way New-York."

\section{ROUX (Antoine)}

Naval designer in Marseille

62 "Ship Lovely Matilda of Philadelphia, Captain Benjamin Huggins." Beautiful water colour drawing. Signed and dated 1808 . I7 by 22 I/ 2 inches Fr. $180-$

\section{RAMON SALAS}

Spanish designer. 19 th century

63 "Coleccion de Costumbres de Quito e Lima, y sus Contornos, Dibujadas por Ramon Salas el anno 1842". Collection of 3 i highly finished water colour drawings representing Peruvian dresses. 4 to. Fr. 80- 


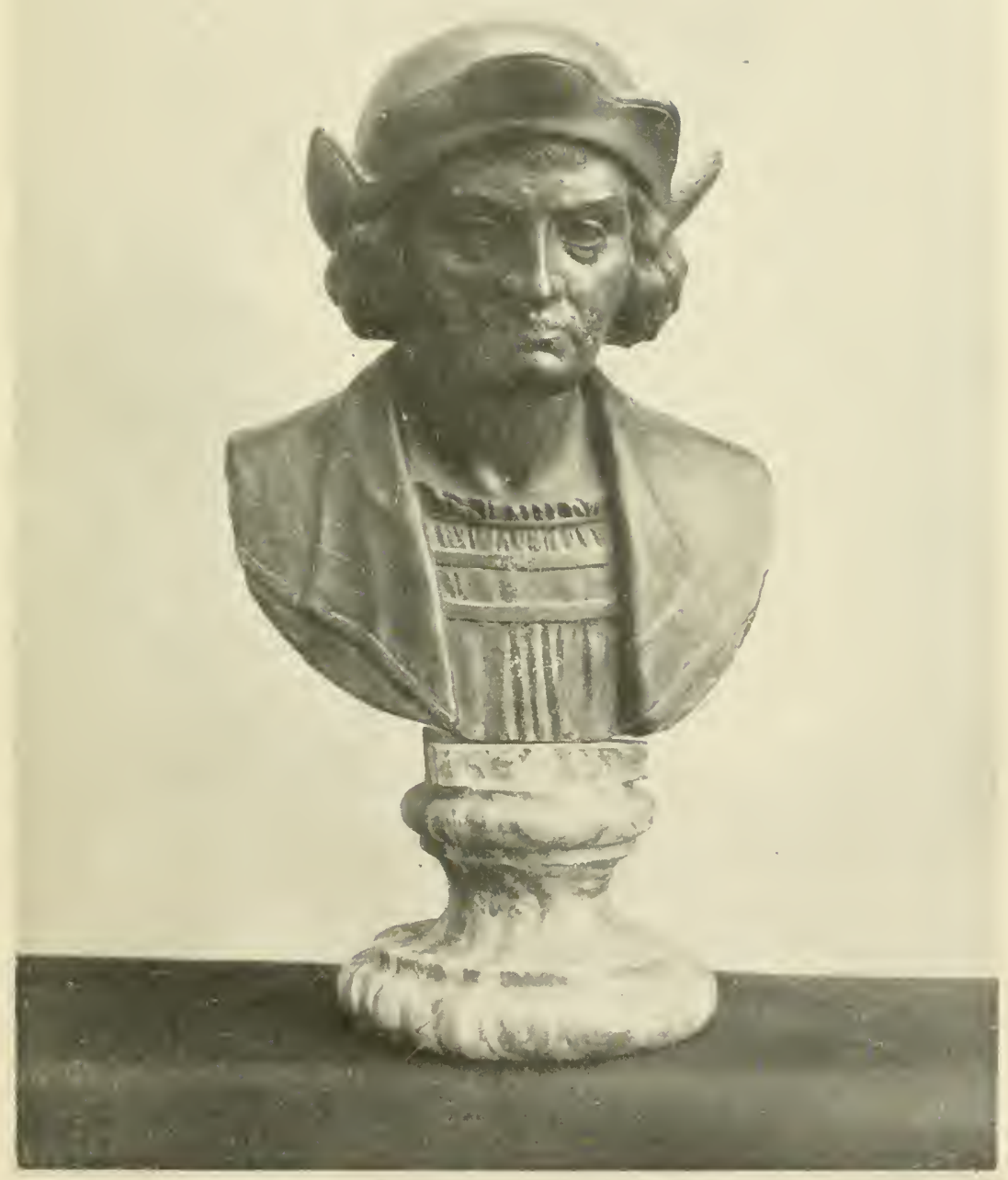

Christopher Columbus.

See No. 175 . 


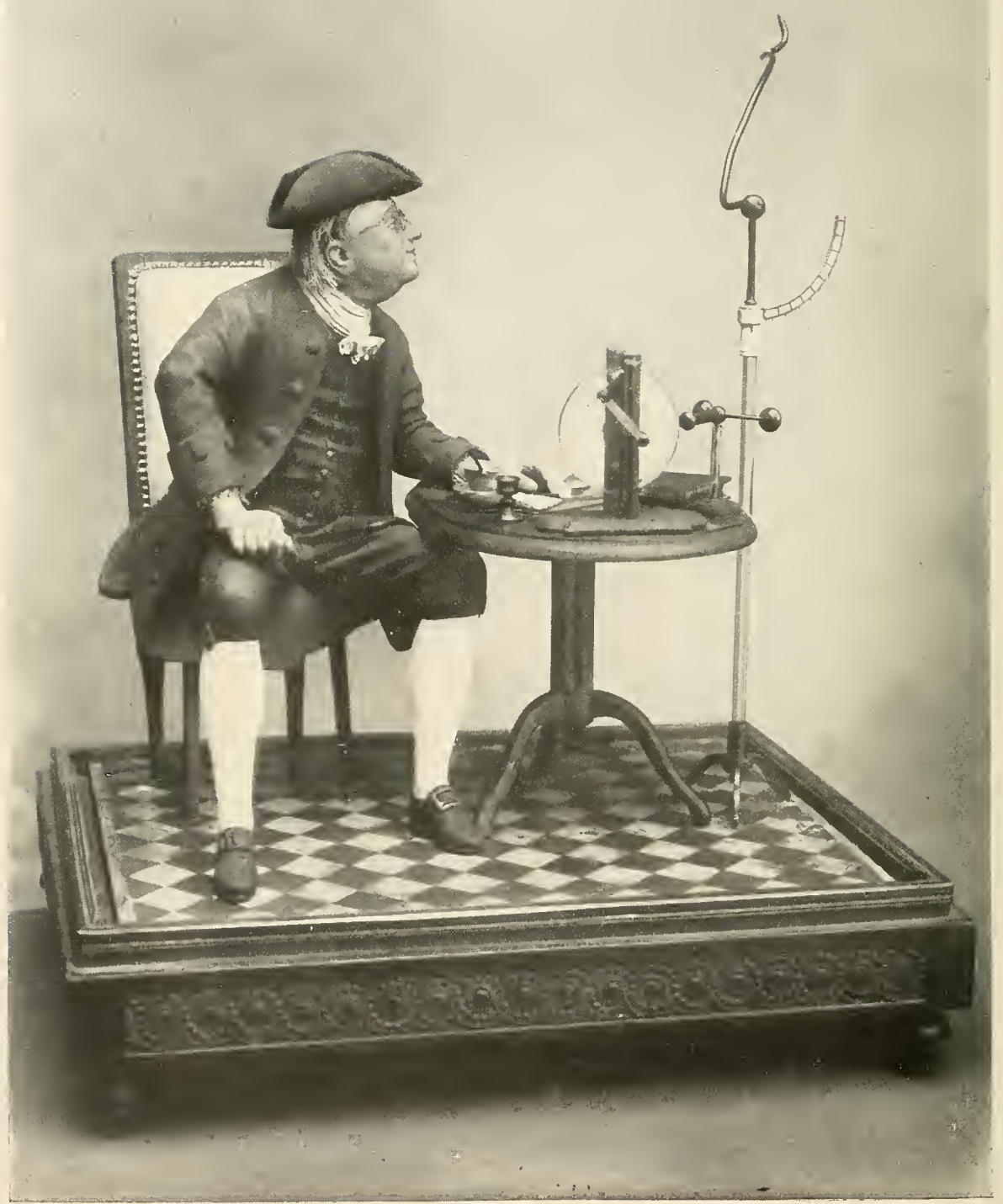

Benjamin Franikin.

See No. I 47. 
SERRES (D.) R. A.

English naval painter and designer. i 8 th century

64 "H. M. S. Amazon upset in a gale off the Island of Martinique, October. 1780". Beautiful sepia drawing. 9 I 2 by 14 I 2 inches. Fr. $200-$

65 H. M. Frigate Amazon running into Antigua, October 1780. Fine sepia drawing. 9 I 2 by I $_{4}$ I 2 inches.

Fr. 200

66 "The Phoenix, the Vigilant, the Greenwich sloop, the Keppel and the Comet forcing the town of Savannah to capitulate, January 1779 ". Very fine sepia drawing of great historical interest. 534 by 10 I 4 inches.

F1. 250

67 "H. M. Frigates Flora and Crescent engaging the Dutch frigates Castor and Brill off the Barbary Coast, May 1781 ". Fine sepia drawing. 7 I 2 by $10 \mathrm{l} / 4$ inches

Fr. $200-$

oS Set of 3 beaufitul sepia drawings representing naval engagements of the American war. 8 I 2 and 9 by I 314 and 15 inches.

Each, Fr. $150-$

\section{STUART, Gilbert) \\ American portrait painter (1 $757-1828)$}

(n) Portrait of John Adams, second president of the U.S.A. Bust directed to right, head nearly full face. Oil painting on panel. Old gilt carved frame. 1 I by 13 inches.

Fr. 2.000 -

The above picture ond the two following are said to have been formerly the property of the Duchess of Leeds, daughter of Senator Caton of Baltimore, an intimate friend of the artist.

70. Photographic facsimile. Fr. $2-$

71 Portrait of Charles Carrol of Carolton, signer for Maryland of the Declaration of Independence. Bust, almost full face. Oil painting on panel. Old gilt carved frame. 16 by 13 inches.

Fr. $2.000-$

See note at the bottom of the foregoing.

72. Photographic facsimile. Fr. $=-$ 
73 Portrait of Edmond Burke, the great British orator and champion of the American liberty cause. Bust, head slightly to left. Oil painting on panel. Old gilt carved frame. I $23 / 4$ by 16 I $/ 4$ inches.

Fr. 2.000 See note at the bottom of $\mathrm{N}^{\circ} 69$.

\section{WARIN (J.B) 1796}

74 "View of Marietta on the Ohio drawn June 12 th 1796 by J. B. Warin". Charming sepia drawing. $5 \mathrm{~s} / 2$ by $73 / 4$ inches.

75 View of the rapids of the Ohio and of Louisville taken from the village of Clarksville. Very pretty sepia drawing. $51 / 2$ by $73 / 4$ inches.

Fr. $50-$

76 View of Long Beach. Charming sepia drawing. $5 \mathrm{I} / 2$ by $73 / 4$ inches.

Fr. 50 -

77 Kaskaskias Chief - Shawanoca Indian. Two beautiful sepia drawings. About I796. 9 by 6 I/2 inches. Each Fr. 25 -

WEISS (J.) 1830

78 Portraits of Washington and La Fayette. Small busts. Pair of sepia drawings probably models for engravings. 6 I $/ 2$ by 5 inches. Each Fr. 20 -

WEST (Benjamin) P. R. A.

Born in Springfield, Pa., in ${ }_{173} 8$. Died in London in 1820.

79 Portrait of Raphael and Benjamin West, sons of the artists, when young, with a dog. Oil painting. Signed and dated, I775. 40 by $3 \mathrm{I}$ inches. Eigteenth century gilt carved frame.

Fr. $5.000-$

From the collection of Benjamin West, having remained in the possession of his family ever since the artist's death.

So The Death of General Wolfe. Beautiful and highly finished oil sketch on panel for his large picture, I 8 by 27 inches. Eigteenth century gilt carved frame.

F. $5000-$

From the collection of Benjamin West himself, having remained in the possession of his family ever since the artist's death.

Ss Photographic facsimile. Fr. 2 - 
$S_{2}$ The Death of General Wolfe. Another fine and highly finished oil sketch on panel for his large picture. 15 by 22 inches. Eigteenth century gilt carved frame.

$$
\text { Fr. } 5.000-
$$

From the collection of G. P. Boyce, R. W. S., late of W'est House, Glebe l'lace, Chelsea. The abore sketch is slightly more advanced than the foregoing.

$\mathrm{S}_{3}$ Benjamin Franklin Discovering Electricity. He is represented full length, seated, head three-quarters to left, with red cloak, the right hand testing the electric spark from a key which is suspended on the string of a kite flying in an electric storm; to the right three cherubs surprised at Franklin extracting electricity from the clouds. Oil painting on panel. Old gilt frame. I 4 by Io inches

Fr. $25.000-$

From the collection of Benjamin West himself, having remained in the possession of his family ever since the artist's death. See illustration.

\title{
WILLE (Johann Georg)
}

Born in Koenigsberg, Hessen, in 1715. Died in Paris in 1815).

85 Assault of Grenada by the French, commanded by Admiral Comte d'Estaing, July 4 th 1779. Admirable sepia drawing. $15 \mathrm{I} 2$ by $22 \mathrm{I} / 4$ inches. Fr. r.000-

\author{
WOOD (Charles C.) \\ Draftsman to the U. S. Frigate Macedonian, $18_{20}$.
}

87 Set of six beautiful water colour drawings representing the voyage of the famous U. S. Frigate "Macedonian" round South America in 1820. 20 by 29 I/ 2 inches. Fr. 1.500

$I^{\circ}$ View of the grand Square in the City of Lima.

$2^{\circ}$ View of San Blas, taken on the spot.

$3^{\circ}$ Panama.

$4^{\circ}$ Callao. Drawn on the spot.

$5^{\circ}$ Valparaiso (With a representation of the Macedonian).

$6^{\circ}$ View of Lima. Exhibiting the Island of San Lorenza. (In the foreground. is the portrait of Wood himself in the act of drawing).

The six water colour-drawings described above are of the highest interest and beautifully finished. They are all signed and dated. The "Macedonian" was the English war ship captured in $18_{12}$ by the frigate " United States" commanded by Stephen Decatur. 


\section{NAMES OF ARTISTS NOT ASCERTAINED}

\section{S8 Portraits of Washington; Franklin; Monroë and Jackson;} Jefferson; Madison; John Adams and J. Quincy Adams. Collection of six beautiful and spirited water colour drawings. Small folio. About I820. Fr. $360-$

The above drawings and the following number seem to have been intented for a set of engraved portraits, which however was never published.

89 Portrait of La Fayette. Water colour-drawing by the same artist as foregoing. 1o by $73 / 4$ inches. Fr. $75-$ This drawing bears the notice: "Teint coloré plus chaud que Franklin".

90 Portrait of Fenimore Cooper. Pretty water colour portrait in the manner of Deveria. $43 / 4$ by $3 \mathrm{I} / 4$ inches. About I8jo.

Fr. 40 -

This clever drawing seems to have been done from life.

9I Licentious allegorical miniature painting referring to. Franklin's efforts to obtain assistance from the French court in gaining the liberty of the American Colonies. Extremely free representations of Louis XVI. Franklin and a female figure (England). Oval. 3 by $2 \mathrm{I} / 2$ inches. In an old leather case.

Fr. I.500 -

This miniature is certainly the work of one of the best French miniature painters (perhaps Hall), as it is of the finest possible work.

92 Portrait of General Horatio Gates. Small outline drawing. About $\mathrm{I} 78 \mathrm{O} .3$ by $2 \mathrm{I} / 2$ inches.

Fr. IO -

93 Portrait of " Sir Charles Hardy, Admiral Anglois en 1779 ". He is represented half length, with cocked hat in an oval border, anchor, flag and ship below. Rough French water colour-drawing. $76 / 8$ by 0 i/8 inches.

Fr. 75 -

Sir Charles Hardy was British governor of New York from 1755 to 1757 .

94. Portrait of General William Henry Harrison, President of the United States, 1841. Half length, directed to left, military uniform. Beautiful sepia drawing, probably from life. $9 \mathrm{I} / 2$ by $7 \mathrm{I} / 2$ inches $\mathrm{Fr} .250-$ 
95 Portrait of General William Henry Harrison, President of the United States. Half length, to right, American eagle flying over him, four flags, cannon and a paper "The Daily Centenal", below. Beautiful sepia drawing by the same artist as preceding. $73 / 4$ by 6 inches.

Fr. $200-$

96 Portrait of General Harrison, President of the United States. Half length to right. Curious sepia drawing I 2 by 9 inches.

Fr. $40-$

97 Portrait of President Van Buren. Half length to right. Curious sepia drawing by the same artist as the foregoing. Same size.

Fr. $40-$

c) $S$ Portrait of General La Fayette. He is represented full bust, in uniform, directed to right, in oval. Admirable pastel painting. About 1789 . II I 4 by $S$ i 4 inches. Gilt frame.

$\mathrm{Fr} .3 .000-$

99 Photographic facsimile. Fr. 2

100 "Adresse au Roi". Curious allegorical calligraphical drawing concerning La Fayette and the incorporation of Martinico with France, July 13 th 1790.2234 by $161 / 2$ inches.

$\mathrm{F}_{1}$. 80

101 La Fayette, Dumouriez and Pichegru. Beautiful circular pen and ink drawing for a snuff box. Diameter 258 inches.

Fr. 125

102 Portrait of Samuel Morse founder of the Morse system of electro-magnetic telegraph. Born in Charlestown, Mass. 1791-IS72. Clever pencil drawing. About 1860. 4 to.

Fr. $45-$

103 Photographic facsimile. Fr. 2 -

This drawing had been reproduced in J. J. Conway's "Footprints of famous Americans in Paris"

104 Portrait of George Washington. Bust in profil to left. Beautiful silhouette portrait fixed on glass. Old wood frame. About 1790. Height of profile 2 i 8 inches; height of frame 534 inches. 
I05 "Indiae Occid. Investigatio Chr. Colombo". Chr. Columbus, holding a flag, followed by his companions, arriving in America and received by the Indians. Beautiful miniature on vellum, probably of the beginning of the 17 th Century or perhaps of an earlier date. 7 by 5 inches.

Fr. $400-$

I06 "Gran Batalla que biexon los Espanoles contra los Araucanos. en Grand Mano al tado del monte Andalicano". Beautiful drawing representing a battle of the Indians against the Spanish troops at the time of F. Cortez, $103 / 4$ by $14 \mathrm{I} / 4$ inches.

Fr. $60-$

Probably by a Spanish designer of the 18 th century.

107 Portraits of Pizarro, Magelhaëns, Hernando de Soto, the conqueror of Florida, Americo Vespucci, Fernando Cortez, Jacques Cartier and Sebastiano Cabot. Clever sepia drawings Middle of the I9th century. Folio. Each, Fr. 20 -

IOS Prise d'un Lougre Anglais par les canots et chaloupes des frégates françaises et espagnoles l'Athalante et la Santa Catharina. Representing the naval engagement of August 15th 1774. Pretty chalk drawing probably by an officer of the Athalante. 9 by 13 3/S inches.

Fr. So -

I09 "Liberty". Curious sepia drawing representing a naval officer handing over to an Indian chief a cap of liberty. The officer is accompanied by other officers and seamen, one of the former holding a flag inscribed "Liberty". About 1815 . $103 / 4$ by $161 / 2$ inches.

Fr. 120

II N Naval battle of the time of the American revolution between the French and English fleets. Beautiful sepia drawing, about 1780.15 by 22 inches. Fr. $80-$

II Plan of Halifax in Nova Scotia Fine water colour drawing. With 24 references. About I790. 6 3/4 by IO $\mathrm{I} / 2$ inches.

Fr. $40-$

Probably by a Cuaadian designer.

I 2 "Plan et élevation du Halifax". Plan of the Canadian vessel "The Halifax". Clever water colour drawing by the same artist as foregoing. About 1790 . $63 / 4$ by I0 $3 / 8$ inches. 


\section{BUSTS AND STATUETTES}

OF

WASHINGTON, FRANKLIN, LA FAYETTE, COLUMBUS, LINCOLN

AND

\section{OTHER PERSONAGES CONNECTED WITH AMERICAN HISTORY}

1 I 4 Bronze bust of George Washington. He is represented full bust, full face, in military uniform, with cocked hat. Pedestal of white marble, gilt edged, small chain wound round, gilt tablet with inscription "Washington". French work. About I780. Height 7 I/2 inches.

Fr. 450

II 5 Bronze bust of George Washington. He is represented half length in uniform, full face. Pedestal of white marble, gilt edged. French work. About i 789 . Height () inches.

Fr. $400-$

II 10 Bust of George Washington in Frankenthal biscuit. He is represented half length, in uniform, head directed to right. Pedestal of white and gilt porcelain. About r 780 . Height $9 \mathrm{I} / 2$ inches.

Fr. $600-$

I17 Pair of gilt bronze statuettes of B. Franklin and George Washington. Both full length. Pedestals in black marble. 18th century. Height 6 I 4 inches.

Beautiful works of art, delicately chased.

The pair Fr. 600 
IIS Terra-cotta bust of George Washington by $J_{*} A$. Houdon. Pedestal in grey marble. Height (including pedestal) $233 / 4$ inches.

Fr. 2500

Houdon accompanied Franklin to America in 1785 , where he modelled for the Congress his celebrated full length statue of George Washington.

However the bust described above is not taken from this statue, but is a terracotta replica (published under the artist's personal direction), of the bust executed in 1801 and which is now exhibited in the Palais de Versailles.

See illustration.

I20 Statuette of George Washington in biscuit de Sèvres.

$\mathrm{He}$ is represented half length, one hand on breast, the other holding a scroll of paper. Pedestal of blue and gilt porcelain. About 1785 . Height $7 \mathrm{I} / 4$ inches.

Fr. $200-$

I2 Coloured porcelain bust of George Washington. Full bust, in civilian dress, head slightly directed to right. English work of the 18 th century. $8 \mathrm{I} / 4$ inches.

Fr. $400-$

I22 Bronze statuette of George Washington. He is represented whole length, full face, in uniform with cloak, right hand holding sword; short pillar covered by a a scroll, to left. About I8oo. Height is inches.

Fr. 5000 -

A fine work of art, admirably chased, representing probably the action of his resigning the generalship.

See illustration.

I 24 Bronze bust of George Washington. Nearly half length, in military uniform, head slightly directed to right. Pedestal of gilt bronze. About ISo6. Height 93/4 inches. Beautifully chased French work. Fr. Iоoo-

I25 Coloured porcelain statuette of George Washington. He is represented full length, with cocked hat, holding in his right hand a paper inscribed "Patrie"; below is the American eagle putting his claws on a broken stone with representations of English emblems. French work of the beginning of the 19 th century. Height I I 3,4 inches. Fr. $300-$

This and the two following items are intented for bottles.

I26 The same. In white porcelain.

Fr. 200 


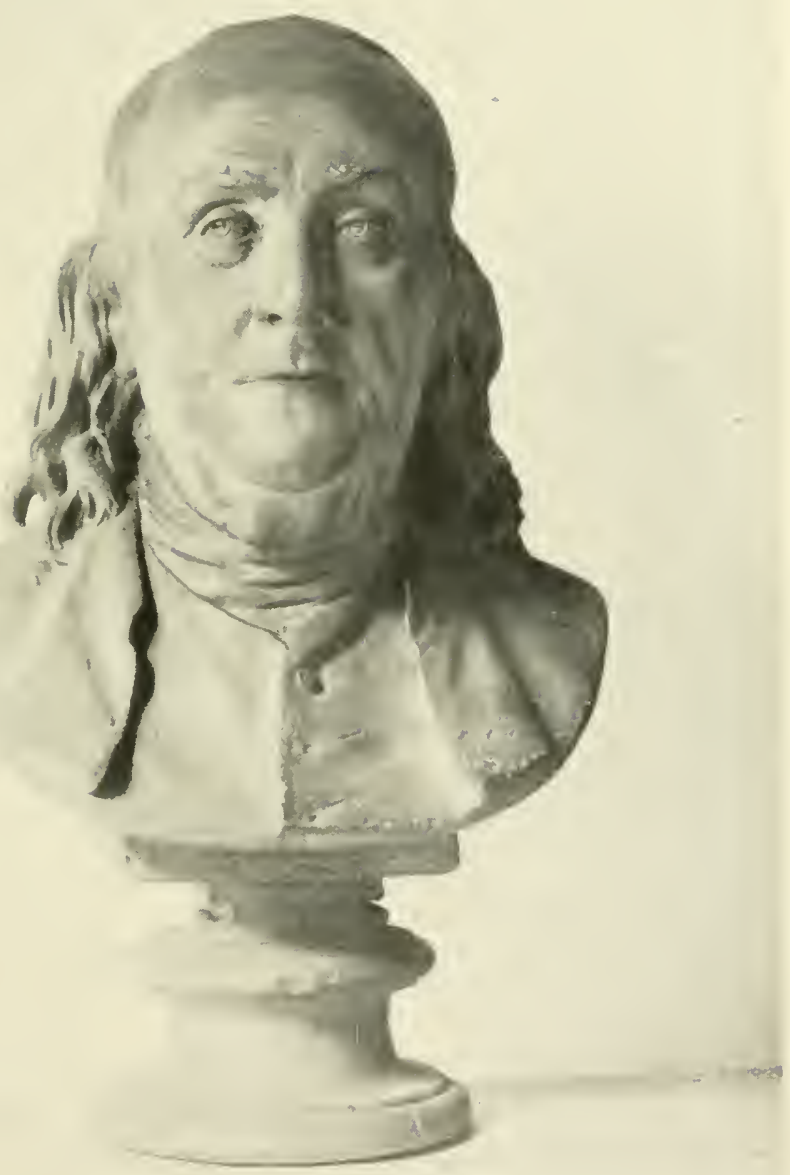

Benjamin Frankin.

See No. 136. 


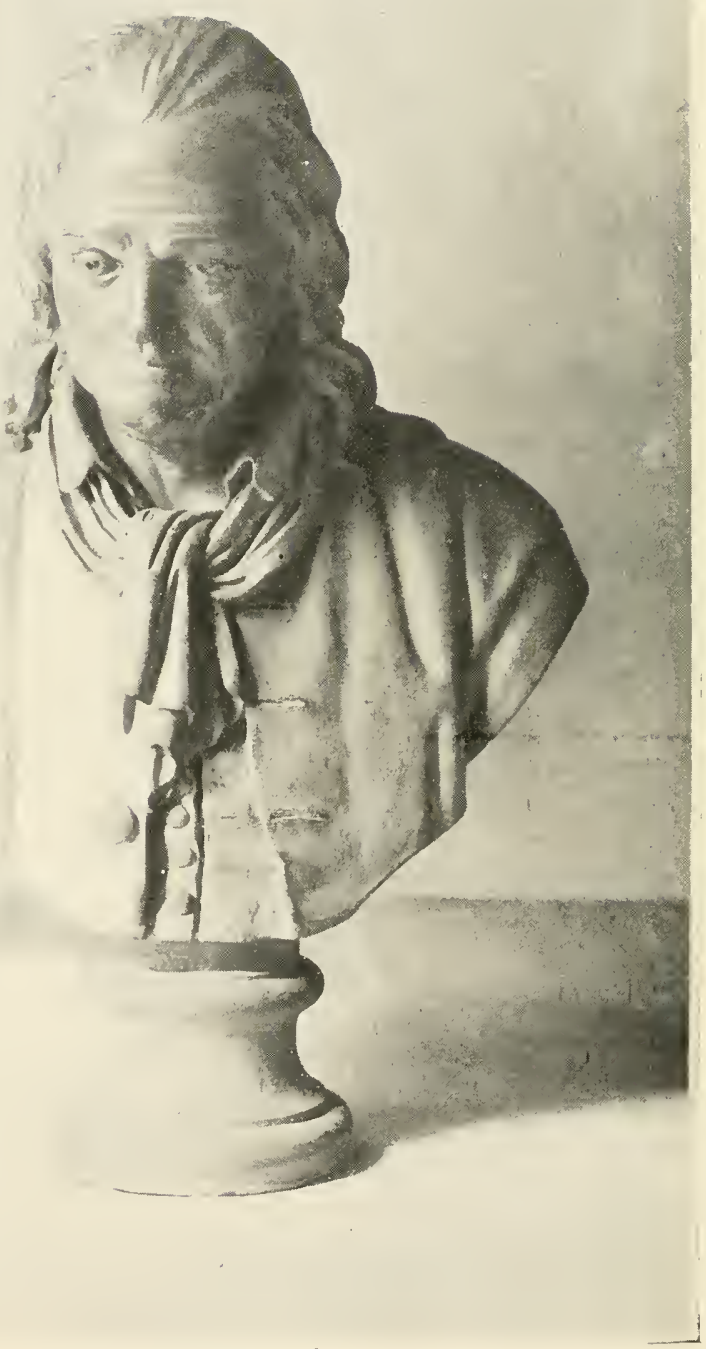

Benjamin Franklin.

See No. 144 . 
I 27 White porcelain statuette of La Fayette of the same make as the two foregoing. He is represented full length, cocked hat, holding paper in left hand, below a cannon. Heigth 12 inches. Fr. $200-$

I 28 Bronze bust of George Washington. He is represented full bust, head slightly to right, hair tied at the back. Admirably chased work of the beginning of the ig th century. Height 8 inches.

Fr. $450-$

129 Plotographic facsimile. Fr. 2

130 Marble bust of George Washington. Bust, head sligthly to right, hair tied at the back (Canova type). In statuary marble. Beautiful work of art, probably of French workmanship. Beginning of the 19 th century. Height I I inches.

Fr. $450-$

I31 Gilt bronze bust of George Washington. Full bust, in military cloak, head slightly to right. Pedestal of black marble. Beautiful work of art of the beginning of the 19 th century. Height I I 2 inches. Fr. $400-$ 132 Photographic simile. Fr. 2 -

133 Life size bust of George Washington in statuary marble. By R. Trentanove. He is represented full face, in a Roman toga. Height, including pedestal, 26 inches.

Fr. $6.000-$

Formerly in the possession of King Charles Albert of Sardaign. Exhibited in the gardens of his castle at Govone near Asti.

See illustration.

135 Bronze bust of George Washington. He is represented full bust, head slightly directed to right, with queue. With an imprint on the back "Reduction mécanique

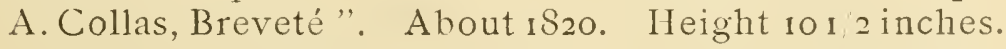

Fr. 250 -

136 Bust of Benjamin Franklin by J. A. Houdon. In "Plâtre teinté terre-cuite" (Plaster tinted terra-cotta colours). Signed and dated, 1777. Height 23 inches.

Fr. $18.000-$

A masterpiece of Houdon differing from the Louve type, which is a little smaller and bears another signature. The above has been undescribed hitherto 
and is of the most skilful and masterly execution, showing in some places the retouches of the master's hand. Like many of the works of Houdon, this bust bears on the back a read seal now undecypherable. It is said that this seal was put on all those of Houdon's works which were sold by auction October 8 th 795 or in that after his death in 1828 . The latter sale produced 5025 Francs for 60 busts, while in 1912 at the Doucet sale 3 busts (two in marble and one in plaster) were sold for 652.300 Francs.

See illustration.

138 Bronze bust of Benjamin Franklin by Houdon. Signed and dated, 1778 . Pedestal in grey marble. Height, including pedestal, $20 \mathrm{I} / 2$ inches. $\quad$ Fr. $3.000-$

The above is an exact replica in bronze of the terra-cotta bust in the Louvre. These replicas were all made under Houdon's direction and generally show signs of having been retouched by the master himself, who is reputed to have been one of the most conscientions artists.

I39 Bronze bust of Benjamin Franklin. Full bust, full face, head very slightly bent (Houdon type). Pedestal of white marble, gilt edged, on black marble slab. About 1778. Height IO $1 / 2$ inches.

Fr. $800-$

I 40 Bronze bust of Benjamin Franklin. He is represented full bust, full face, with coat showing three buttons. Pedestal in white and black marble. About 1778 . Height I2 I/2 inches. Fr. $400-$

I4I Bronze statuette of Benjamin Franklin. He is represented full length, head slightly directed to right, holding his hat under his left arm and in his right hand a scroll partly unrolled. About 1780 . Marble pedestal. Height (including pedestal) 19 inches. Fr. 2.000See illustration:

I 43 The same. In terra-cotta tinted plaster. Height i6 I/4 inches.

Fr. $200-$

144 Life size terra-cotta bust of Benjamin Franklin. He is represented full bust, head very slightly turned to left and a little bent, open collar and neck cloth, long hair falling on both shoulders. Admirable eigteenth century bust by an unknown artist, certainly executed from life. About I780. Height of the bust $23 \mathrm{I} / 2$, with pedestal 30 inches.

Fr. 7.500 -

See illustration. 
I46 Coloured porcelain statuette of Benjamin Franklin. He is represented full length holding his hat in one hand and a half open scroll in the other hand. English work of the 18 th century. Height is $3 / 4$ inches.

Fr. Soo -

147 Full length statuette of Benjamin Franklin in the act of discovering electricity. He is represented seated by a table, on which are an electrical apparatus of glass and wood and other scientific instruments, etc. The whole is covered by a glass case pierced by a round hole through which passes a metal wire representing lightening; Franklin looks up to watch the result of his invention. The figure of Franklin, the table, etc., are of painted plaster and wood, the chair on which he is seated is upholstered in green silk. The whole stands on a square piece of wood inlaid and framed by an engraved bronze border. About 1780 . Height of the figure 9 inches; height of the whole 12 inches.

Fr. 5.000 -

A very curious and unique relic of Franklin being at the same time an admirable work of art. It is supposed that the artist used Franklin's own hair for the wig.

See illustration.

I 49 Marble bust of Benjamin Franklin. He is represented full bust, draped, hair falling over both shoulders, head slightly turned upwards and to left. In white statuary marble. About i 770 . Ileight ri inches. Fr. 2.000-

Beautiful work of art bearing the following notice on a label: "Bust of Franklin by Canova. Purchased in Rome early in the present century. New Haven, $1855 "$.

I50 Photographic facsimile. Fr. 2

I5I Bronze statuette of Benjamin Franklin. He is represented full length, right hand holding his hat, and supporting his right arm. About isoo. Height 30 inches.

Fr. $1.800-$

See illustration.

153 Terra-cotta statuette of Benjamin Franklin, hy G. Peiron. He is represented full length in the dress of an Italian noble, with fur cap and long cloak, open in front and 
skowing a belt. Beginning of the rgth century. Height 24 I/2 inches.

Fr. I.000-

154 Photographic facsimilc. Fr. $2-$

I55 Bust of Benjamin Franklin, in biscuit. He is represented full bust, full face. Pedestal of yellow and gilt porcelain. French work of the beginning of the rgth century. Height 8 inches.

Fr. $120-$

156 Bronze statuette of Benjamin Franklin. He is represented full length, sitting on a chair, left hand holding book, three large volumes entitled " Physique I750, Chimie, Economie" underneath the chair. Beautifully chased French work of art of the beginning of the Igth century. Height 22 inches.

Fr. $1.200-$

See illustration.

158 Bronze statuette of Benjamin Franklin. He is represented full length, head slightly to left, long coat trimmed with fur. About 1800 . Height $3 \mathrm{I} / 4$ inches. Fr. 60 -

I59 The same. Mounted on a seal, the figure forming the handle. Height 3 I/2 inches.

Fr. $80-$

I60 Bronze bust of Benjamin Franklin. He is represented full bust, full face, with coat showing four buttons. Ebony pedestal. About I815. Height I2 inches.

Fr. $200-$

I6I Bronze bust of Benjamin Franklin. Head slightly directed to right, with coat showing three buttons. Marble pedestal. "F. Barbedienne Fondeur". About 1825. Height, I I $1 / 2$ inches.

Fr. $250-$

Beautiful early cast.

I62 Bust of Franklin. Composition of plaster in imitation of ivory. Signed "Chardigny f' $\mathrm{I}_{55} \mathrm{I}$, Hylorin et $\mathrm{C}^{\mathrm{ie}}$, Editeurs". Height 5 inches. Fr. $30-$

163 Plaster bust of Benjamin Franklin. Full face. Signed on back "Chardigny 1854 ". Height 9 inches.

Fr. $50-$ 
164 Bust of Franklin. In "biscuit de Sèvres". Full bust, full face. Pedestal of blue porcelain. With inscription "Sèvres E. R. 93, 2, LV". Height 9 I'4 inches.

$\mathrm{Fr}_{1} .200-$

165 Bronze bust of La Fayette. Full bust, in uniform, with star of Saint Louis, head slightly to left. Pedestal of white marble, gilt edged, on black marble slab. About 17S9. Height $101 / 2$ inches.

Fr. Soo -

166 Bronze bust of La Fayette. Full bust in uniform, with star of Saint Louis, full face. Pedestal of green and grey veined marble, gilt edged, with chain and tablet. About i7S9. Height 1014 inches. Fr. $600-$

167 Bronze statuette of General La Fayette. Pedestal in green marble. He is represented full length, in uniform, bareheaded; beside him a small seat with cushion and crown. About 1830 . Height 6 i 2 inches.

Fr. So -

I6S Bronze bust of General La Fayette. He is represented full bust, full face, in uniform. Pedestal in bronze. About 1830 . Height 434 inches. Fr. 60-

I69 Another bronze bust of General La Fayette, similar to foregoing. Pedestal in finely chased bronze. Height $4 \mathrm{I} / 2$ inches.

Fr. 75 -

I 70 Terra-cotta bust of Abraham Lincoln. He is represented full bust, head slightly directed to right. Signed on the back: "D'Osmond, Paris, octobre iS65". Height 12 inches.

Fr. $200-$

I7I Bronze statuette of Abraham Lincoln. He is represented full length, left hand resting on two books and a paper inscribed "Abol.. Slave..". By Pfeiffer, 1865. Height $13 \mathrm{I} / 4$ inches.

Fr. 250 -

172 Bronze bust of Abraham Lincoln. Head slightly to right. By Emile Guillemin. Signed. Height 9 inches.

Fr. $100-$

I73 Bronze bust of Abraham Lincoln. Full bust, full face. Height $93 / 4$ inches.

Fr. IOO -

Beautifully chased work of art. 
I 74 Bronze bust of Abraham Lincoln. Full bust, head very slightly directed to left. Height $53 / 4$ inches. Fr. 80Admirably chased.

I75 Bronze bust of Christopher Columbus. He is represented full face, wearing head covering. Fine old bronze of the beginning of the i 7 th century. Marble pedestal. Height (including pedestal) 15 inches.

See illustration.

Fr. $3.000-$

I76 Terra-cotta statuette, presumed portrait of La Gallissonnière, the celebrated governor of Canada. He is represented full length, in naval uniform, left hand on sword, the right holding a sheet of paper. Signed to right "H. Gruyère". First half of the r th century. Height 16 I/2 inches. Fr. $200-$

Formerly in the collection of Mr. V. Margry, the celebrated historian and cosmographer.

177 Coloured porcelain statuette of José Antonio Paez general and first president of Venezuela (I790-1873). He is represented full length, in uniform, holding laurel wreath in right hand. Beside him a mortar with a cannon ball as stopper, the whole forming an inkstand. About r83o. Height $73 / 4$ inches.

Fr. $75-$

I7 9 Pair of bronze busts of the Generals Winfield Scott and Lee. About is6o. Height i5 inches.

The pair Fr. I20 -

I79 Terra-cotta statuette of F. Sauvage, the inventor of the screw-propellor. He is represented full length, left arm resting on a screw. Signed: "E. Blot I86I".

Fr. $50-$ 
MEDALLIONS WITH PORTRAITS IN RELIEF OF CELEBRATED AMERICANS

ISo Pair of circular medallion portraits of J. B. Boyer and Alex Petion, Presidents of Haiti. In bronze dor repoussé. By Tivier. Diameter 234 inches. The pair, Fr. $75-$

I8 I Circular bronze medallion with relief portrait of Chr. Columbus, struck in commemoration of the fourth centenary. Diameter 4 I 2 inches.

Fr. IO -

${ }_{1} S_{2}$ Circular bronze medallion with relief portraits of James Fenimore Cooper. He is represented in profil to right. About 1840 . Diameter 5 I 2 inches.

Of the finest execution.

Fr. 175

$I_{3}$ Circular bronze medallion with relief portrait of Fenimore Cooper. By David d'Angers, 1835. Diameter 6 inches.

Fr. $90-$

184 Oval bronze medallion with relief portrait of Benjamin Franklin. Bust in profil to right. About 178o. Gilt frame. 212 by 2 inches.

Fr. $100-$

I 85 Oval bronze medallion with relief portrait of Benjamin Franklin. Bust in profile to right, with fur cap. About 17 So. 2 i/ 4 by 2 inches.

Fr. So -

186 Oval bronze medallion with relief portrait of Benjamin Franklin. Bust in profile to right. Square candle wood frame with gilt bronze stars in the corners. About I78o. $23: 4$ by 2 I/ 4 inches. Fr. $200-$ 
I87 The same. In gilt bronze and gilt bronze frame.

Fr. $200-$

I88 Relief portrait of Benjamin Franklin in bronze, rather roughly sculpted, screwed on white marble. He is represented full bust in profile to left. About i8oo. Old oval gilt carved frame. Height of bust 8 inches, height of frame 13 inches.

Fr. I25-

I89 Oval bronze medallion with relief portrait of Benjamin Franklin. Head in profile to left, surrounded by the inscription "B. Franklin Bienfaiteur de l'humanité, 1776". 3 by $23 / 4$ inches.

Fr. $200-$

I 90 The same. In gilt bronze.

Fr. $200-$

I9I Oval gilt bronze medallion with relief portrait of Benjamin Franklin, same as foregoing: laurel wreath instead of inscription. $33 / 4$ by $23 / 4$ inches.

$$
\text { Fr. } 200-
$$

192 Circular bronze medallion with relief portrait of "Docteur Franklin." Bust in profile directed to right. In gilt bronze frame. Diameter $4 \mathrm{I} / 4$ inches.

Fr. $100-$

193 Oval gilt bronze medallion with relief portrait of Benjamin Franklin. Bust in profile directed to right, coat trimmed with fur, opened in front. Gilt bronze frame. About i78o. $33 / 4$ by 3 inches.

Fr. 175 -

I94 Oval bronze medallion with relief portrait of Benjamin Franklin. Bust in profile, directed to right, with fur cap, (Nini type). About $1780.23 / 4$ by 2 inches.

Fr. I 00

I95 Oval Wedgwood black medallion with relief portrait of Benjamin Franklin. Bust in profile to right. About 1780. 3 by 2 I/2 inches.

Fr. $150-$

I96 Circular medallion with relief portrait of Benjamin Franklin in biscuit de Sèvres. Head in profile to left, Curled hair, white on blue ground. About i78o. Old gilt carved frame. Diameter 4 I/S inches. Fr. Ioo- 


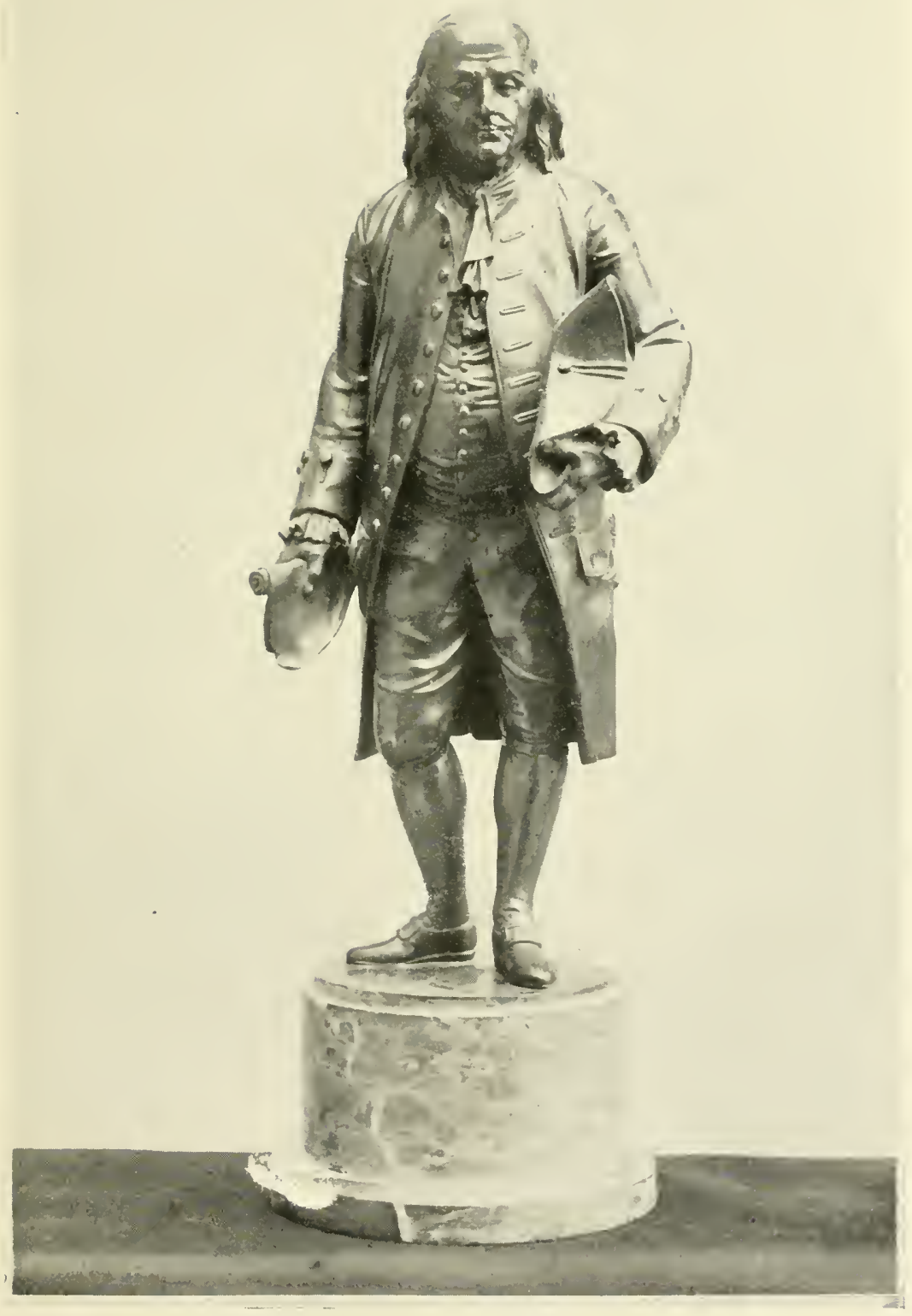

Benjamin Franklin.

See No. 141. 


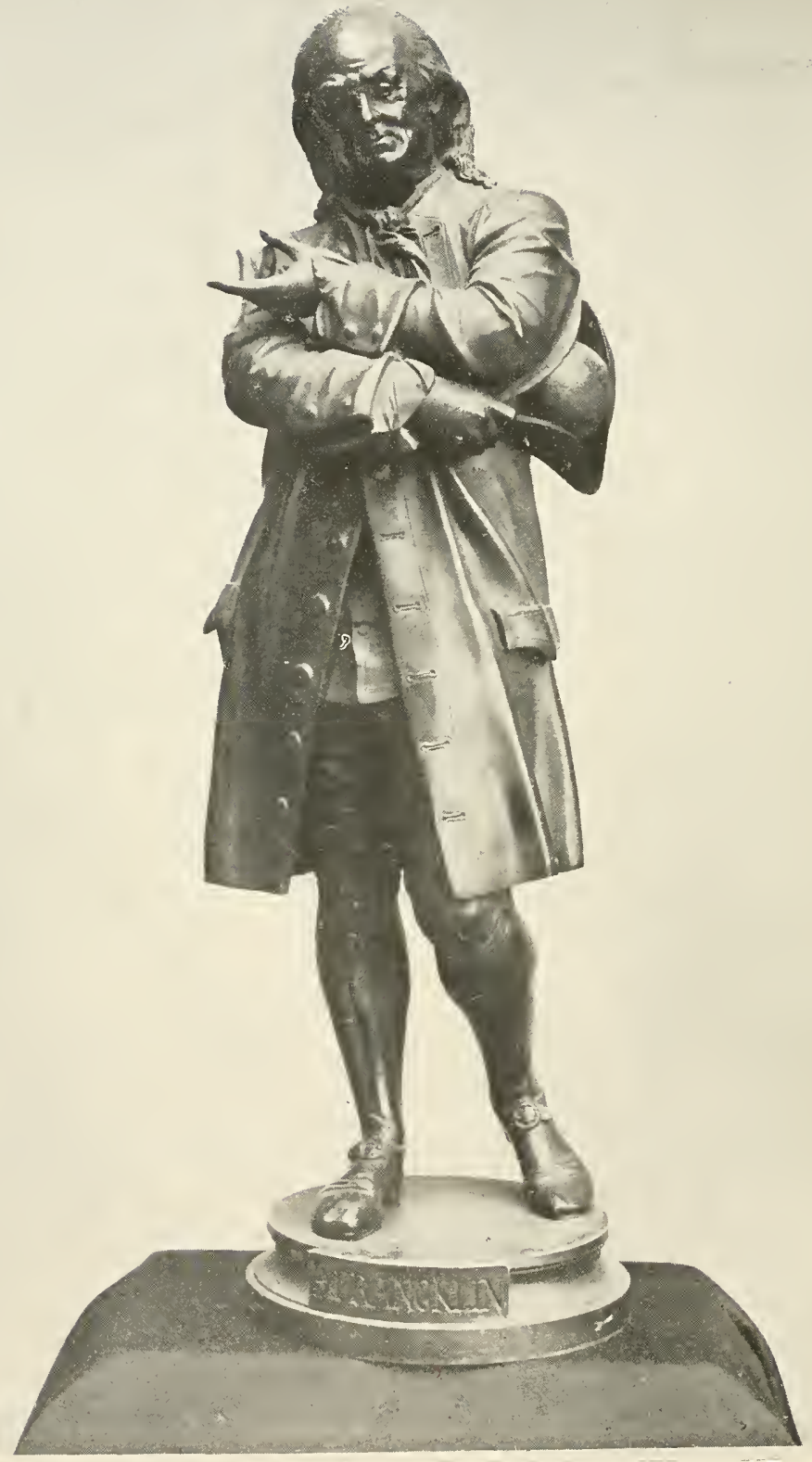

Benjamin Franklin.

See No I5I. 
I97 Circular medallion with relief portrait of Benjamin Franklin in biscuit de Sèvres. About i 7 So. Height of bust 2 inches, diameter of medallion $31 / 4$ inches.

Fr. 125 -

I 98 Medallion portrait in relief of Benjamin Franklin in biscuit de Sèvres. Bust in profile to right, white on blue ground. About i78o. Oval gilt carved wood frame. I $\equiv / 16$ by 2 10/16 inches.

Fr. I $20-$

199 Circular medallion with portrait in relief of Benjamin Franklin, in biscuit de Sèvres. Bust in profile to right, white on blue ground Old gilt bronze frame with loop of ribbon. Height of bust $1 / 2$ inch, diameter including frame 2 inches. About 1780 .

Fr. $100-$

200 Circular medallion with portrait in relief of Benjamin Franklin, in biscuit de Sèvres. Bust in profile to right. White on same ground. Gilt carved wood frame. About i78o. Diameter I I 2 inches. Fr. Ioo-

201 Circular medallion with portrait in relief of Benjamin Franklin, in biscuit de Sèvres. Bust in profile to right. White on green silk ground. Old carved frame in black.
About I 780 .
Diameter 2 inches.
Fr. $125-$

202 Circular medallion with portrait in relief of Benjamin Franklin, in biscuit de Sèvres. Bust in profile to right; white on same ground. Frame in carved wood, white and gold. About r78o. Diameter 358 inches.

F1. $150-$

203 Circular terra-cotta medallion with relief portrait of Benjamin Franklin by J. B. Nini. Bust in profile to left, fur cap. With inscription "B. Franklin A méricain". Signed "Nini F. 1777." Diameter $45 / 8$ inches.

F1. I 00

Jean Baptiste Nini, born in Arbino, Italy 1717 , died at Chaumont, 1786 , was one of the most celebrated and gifted sculptors in terra-cotta. He came to France in the early part of the reign of Louis XVI. and set up his manufactory of terracotta medallions in the castle of Chaumont belonging at that time to Le Ray de Chaumont and now the property of the Prince de Broglie.

204 Circular terra-cotta medallion with relief portrait of Benjamin Franklin, by Nini, similar to foregoing but I $/ 4$ inch smaller. Signed "Nini F. 1777." Fr. I0o- 
$20 ;$ Circular terra-cotta medallion with relief portrait of Benjamin Franklin, by Nini, similar to foregoing type, but wearing spectacles. Signed, "Nini F." Diameter $3 \mathrm{I} / 2$ inches.

Fr. $400-$

Of the greatest rarity, only a few specimens known.

206 Circular terra-cotta medallion with relief portrait of Benjamin Franklin, by Nini. Bare head in profile to left, hair falling over shoulders. With inscription, " Eripuit Coelo Fulmen Sceptrumque Tirannis." Signed "Nini F. I779." Diameter 6 inches. Fr. $400-$

207 The same. In bronze tinted plaster and glazed. Beautiful impression probably a proof.

Fr. $120-$

208 The same. In bronze tinted plaster, but not glazed.

Fr. $40-$

209 The same. In bronze. Diameter 5 I/4 inches. Fr. $150-$

2 Io Circular zinc medallion with relief portrait of Benjamin Franklin, by Nini ; same type as $\mathrm{N}^{\circ} 203$. Old square mahagony frame. Diameter $3 \mathrm{I} / 2$ inches. Fr. Ioo-

21 I Collection of 5 terra-cotta medallions and one in bronze with relief portraits of Benjamin Franklin, by Nini, the six mounted in a ISth century gilt carved frame. Size of frame $17 \mathrm{I} / 2$ by 22 inches. The lot Fr. $1.250-$

Containing the large type, described in No 206 , the small with spectacles, described in No 206, three specimens of No 203-204; each slightly different and a copy of the latter in old bronze.

212 Photographic facsimile. Fr. 2 -

2 I3 Boxwood medallion with relief portrait of Benjamin Franklin. Bust, slightly directed to right, coat trimmed with fur, long hair. Mounted on blue velvet in gilt rimmed ebony frame. is th century. 6 by $5 \mathrm{I} / 2$ inches.

Fr. 75 -

214 Oval ivory medallion with relief portrait of Benjamin Franklin. Bust in profile to right. Old gilt carved frame. $33 / 4$ by 3 inches.

Fr. I25 -

215 Circular medallion in bronze repoussé with relief portrait of La Fayette. He is represented full bust in 
uniform, profile directed to lelt. Inscribed "Le Général Lafarette, Dédié à la Garde Nationale." Gilt bronze frame. About 18 jo. Diameter 5 inches. Fr. So -

2 I6 Circular bronze medallion with relief portrait of La Fayette. Bust to front, head directed to left, crowned with a laurel wreath. To right, "Au Général Lafarette P.J. David." About I $S_{20}$. Diameter $63 / 4$ inches.

Masterpiece by the celebrated sculptor David d'Angers.

217 Circular bronze medallion with relief portrait of Général La Fayette, by David d'Angers, 1830 . Head in profile to left. Diameter $41 / 2$ inches. Fr. $75-$

2 I 8 Circular medallion with relief portrait of La Fayette, in bronze d'argent, struck for the celebration of the centenary, with inscription "Lafayette, I776-1870." Diameter 7 I:4 inches.

Fr. $25-$

219 Circular bronze medallion with delicately chased relief portrait of La Fayette. Head in profile to left. Diameter $5 \mathrm{I} / 4$ inches. Ebony frame, gilt rimmed, with 4 stars in the corners. About $1 S_{20}$. Fr. $200-$

220 Circular bronze medallion with relief portrait of P. Lery of the U.S. Navy. By David d'Angers. Diameter $63 / 4$ inches.

Fr. 75 -

221 Circular medallion with relief portrait of Abraham Lincoln in pressed wood. Head in profile to right. About I860. Diameter 43.4 inches. Fr. 40 -

222 Pair of circular bronze medallions with relief portraits of Benjamin Franklin and George Washington. The portrait of Washington is signed "P. 1846"; both bear French inscriptions. In circular gilt frames.

The pair. Fr. 250

223 Three circular bronze medallions with relief portraits of Washington, Franklin and Jefferson. By Henry Kirke Brown, Chicopee 1852 . Diameter of each, Io inches.

The lot. Fr. I.500 -

Of the finest workmanship and the most delicate chasing. Henry Kirke Brown, one of the best American sculptors, was born in Leyden, Mass, 1814 and 
died in Newbury, N-Y, ro July 1886. His artistic career will always be noteworthy as covering the whole period of American sculpture from its very beginning until a time when American sculptors had worked their way to the foremost rank of contemporary artists.

224 Photographic facsimile. Fr. 2 -

225 Oval bronze medallion with relief portrait of George Washington. Head in profile to left (Dupré type). Beginning of the 19 th century. 8 by $63 / 4$ inches.

Beautiful work of art, admirably chased.

Fr. $300-$

226 The same. In bronze tinted plaster. Ol gilt carved frame with ornamental heading.

Fr. 75 -

227 Very small gilt bronze medallion with relief portrait of George Washington. Bust in profile to right. Oval height $5 / 8$ inches.

Fr. $25-$

228 Circular bronze medallion finely chased with relief portrait of George Washington. Head in profile to right, with flowing hair. Ebony trame. Diameter 3 inches.

Fr. $200-$

229 Circular bronze medallion with relief portrait of Washington. Head in profile to right, hair tied at back with long ribbon. Inscribed below "Washington" with monogram "T." Old gilt rimmed ebony frame. Middle of the 19 th century. Diameter without frame $43 / 4$ inches.

Fr. $60-$

230 Circular medallion with relief portrait of George Washington in fonte de Berlin. Head in profile to right. About isoo. Diameter 6 I/4 inches. Fr. $150-$

23 I Circular Wedgwood medallion with relief portrait of George Washington. Head directed to left, white on blue ground. Old gilt carved frame. About I 780. Diameter 4 inches.

Fr. $200-$

232 Oval Wedgwood black medallion with relief portrait of Washington. Head in profile, directed to left, hair tied at back. About 1785. 7 by 6 i' 4 inches. Fr. $300-$ 
233 Circular medallion of pressed wood with relief portrait of George Washington. Head in profile, directed to left. About I860. Diameter 4 i/4 inches. Fr. $40-$

234 Circular medallion portrait of George Washington, stamped on card board, white on red ground. About IS25. In narrow gilt bronze frame. Diameter $13 / 4 \mathrm{in-}$ ches.

Fr. $40-$

235 Circular ivory medallion, with relief portrait of George Washington. Head in profile, to right, tied at back. About 1800 . Narrow gilt bronze rim. Diameter 2 inches.

Fr. 75 -

236 Very small zinc medallion with relief portrait of George Washington. Bust in profile to right, in military uniform, scroll beneath. Oval height I inch. IS th century.

Fr. $30-$

237 Very small zinc medallion with relief portrait of George Washington, similar to foregoing, but without scroll. Oval height $3 / 4$ inch.

Fr. $25-$ 


\title{
OLD SNUFF BOXES, BONBONNIERES
}

\author{
AND ETUIS
}

\section{OF AMERICAN HISTORIAL IMPORTANCE}

238 Circular box wood snuff box, lined with tortoiseshell; on the lid gilt bronze medal of Washington, dated "Feb. II i $78_{2}$ ". Diameter, 3 inches. Fr. I20-

239 Circular tortoiseshell snuff box, gilt rimmed; on the lid medallion portrait of Washington in bronze d'or repoussé. Signed "Morel fils fec". About r79o. Diameter $27 / 8$ inches.

Fr. $150-$

240 Circular tortoiseshell snuff box, gilt rimmed; on the lid coloured miniature painting on porcelain of General Washington. He is represented full bust, in civilian dress, slightly directed to left. After the painting by Gilbert Stuart. About I8Io. Diameter $3 \mathrm{I} / 4$ inches. Fr. $200-$

24I Circular ivory snuff box, gilt rimmed; on the lid medallion portrait of Washington, stamped on cardboard. $\mathrm{He}$ is represented head in profile to left, white on brown ground. About I8I5. Diameter 2 I/2 inches Fr. 80 -

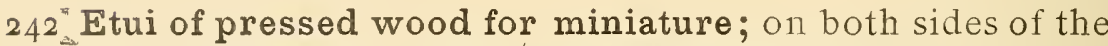
lid medallion portrait of George Washington surrounded by American emblems, the whole in relief. About $1820.3 \mathrm{I} / 4$ by $3 \mathrm{r} / 2$ inches. Fr. So - 
243 Etui of pressed wood for miniature; on the lid portrait of Washington on horseback on a monument, surrounded by American emblems, the whole in relief. About IS2o. 614 by 5 inches.

Fr. $100-$

244 Circular snuff box in foreign wood, gilt rimmed; on the lid medallion relief portrait of $\mathbf{B}$. Franklin in bronze, beautifully engraved. About i778. Diameter 434 inches.

Fr. $350-$

245 Circular box wood snuff box, gilt rimmed; on the lid bronze medal of B. Franklin by Dupré. About 1780. Diameter 3 inches.

Fr. 120

246 Circular box wood snuff box, gilt rimmed; on the lid medallion portrait of $\mathbf{B}$. Franklin in bronze d'or repoussé. About isoo. Diameter 2 I 4 inches. Fr. 125 -

247 Circular ebony snuff box, gilt rimmed; on the lid miniature painting on porcelain of B. Franklin after the portrait by Duplessis. About isio. Diameter $3 \mathrm{I} / 4$ inches.

Fr. 200 -

$24 S$ Circular tortoiseshell snuff box, gilt rimmed; on the lid same subject as the previous. Diameter 3 inches.

Fr. 200

249 Circular ivory snuff box, gilt rimmed, lined with tortoiseshell; on the lid medallion portrait of B. Franklin, stamped on cardboard. Head in profile to left, white on blue ground. About 1815 . Diameter 2 I/4 inches.

Fr. $75-$

250 Circular tortoiseshell snuff box, gilt rimmed; on the lid aquatint printed in colours (by Janinet), representing Franklin, Voltaire and Rousseau. About i788. Diameter 3 inches.

Fr. 200

25I Circular candle wood snuff box, gilt rimmed, lined with tortoiseshell; on the lid same picture as foregoing. Diameter 3 inches.

$\mathrm{Fr}_{1}$. 175

252 Circular tortoiseshell snuff box, gilt rimmed; on the lid same subject as the two foregoing with the difference that this is a stipple engraving printed in colours. About ${ }_{7}$ 8S. Diameter 2 15/16 inches. Fr. $175-$ 
253 Circular tortoiseshell snuff box, gilt rimmed; on the lid stipple engraving in colours representing the busts of Franklin, Rousseau and Voltaire on a pyramid, surrounded by three cupids. With inscription "Aux Amis de la vérité la Postérité reconnaissante". About I79o. Diameter 3 I/4 inches.

Fr. $150-$

254 Circular tortoiseshell snuff box, gilt rimmed; on the lid miniature in "grisaille", representing Franklin, Rousseau and Voltaire, in profiles to right. About I780. Diameter 23,8 inches.

Fr. $400-$

This beautiful miniature is attributed to Sauvage.

255 Circular box wood snuff box; on the lid three portraits on one medallion of Franklin, Rousseau and Voltaire, carved in ivory. About i 7 So. Diameter 4 inches

Fr. $300-$

256 Circular ivory snuff box, gilt rimmed; on the lid colour print, portrait of La Fayette. He is represented full bust, in uniform, profile to left. About I789. Diameter 2 I 2 inches.

F1. I $25-$

257 Circular ivory snuff box, gilt rimmed, lined with tortoiseshell; on the lid portrait of La Fayette, colour print by $M^{\text {1le }}$ Juillet. He is represented full bust in uniform, profile to left. About i789. Diameter 3 inches.

Fr. $125-$

258 Circular box wood snuff box, beautifully veined; on the lid fine water colour portrait of La Fayette. Bust, in uniform, slightly directed to left. About i 789 . Diameter $33 / 16$ inches.

Fr. $125-$

Has been repaired.

259 Circular box wood snuff box, gilt rimmed; on the lid medallion portrait of La Fayette in physionotrace by Quenedey. About 1789. Diameter 3 inches.

Fr. $100-$

260 Circular bronze snuff box beautifully chased, of the First Empire; on the lid portrait of La Fayette in colour print ( $\left.{ }_{7} 89\right)$. He is represented full bust, in uniform, profile to right. Diameter $25: 8$ inches. Fr. I50- 


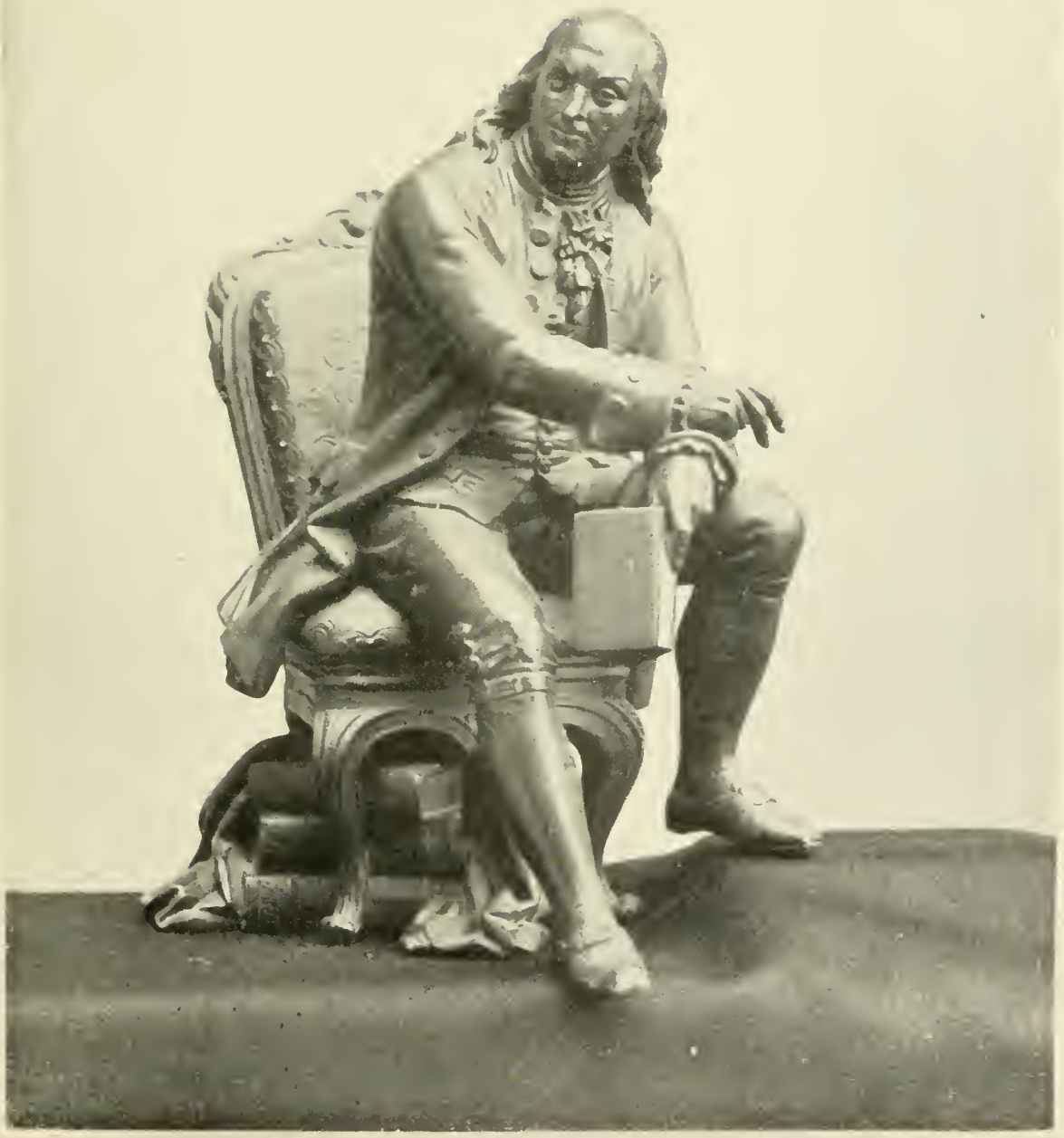

BeNJamin FrankLiN.

See No. 156. 


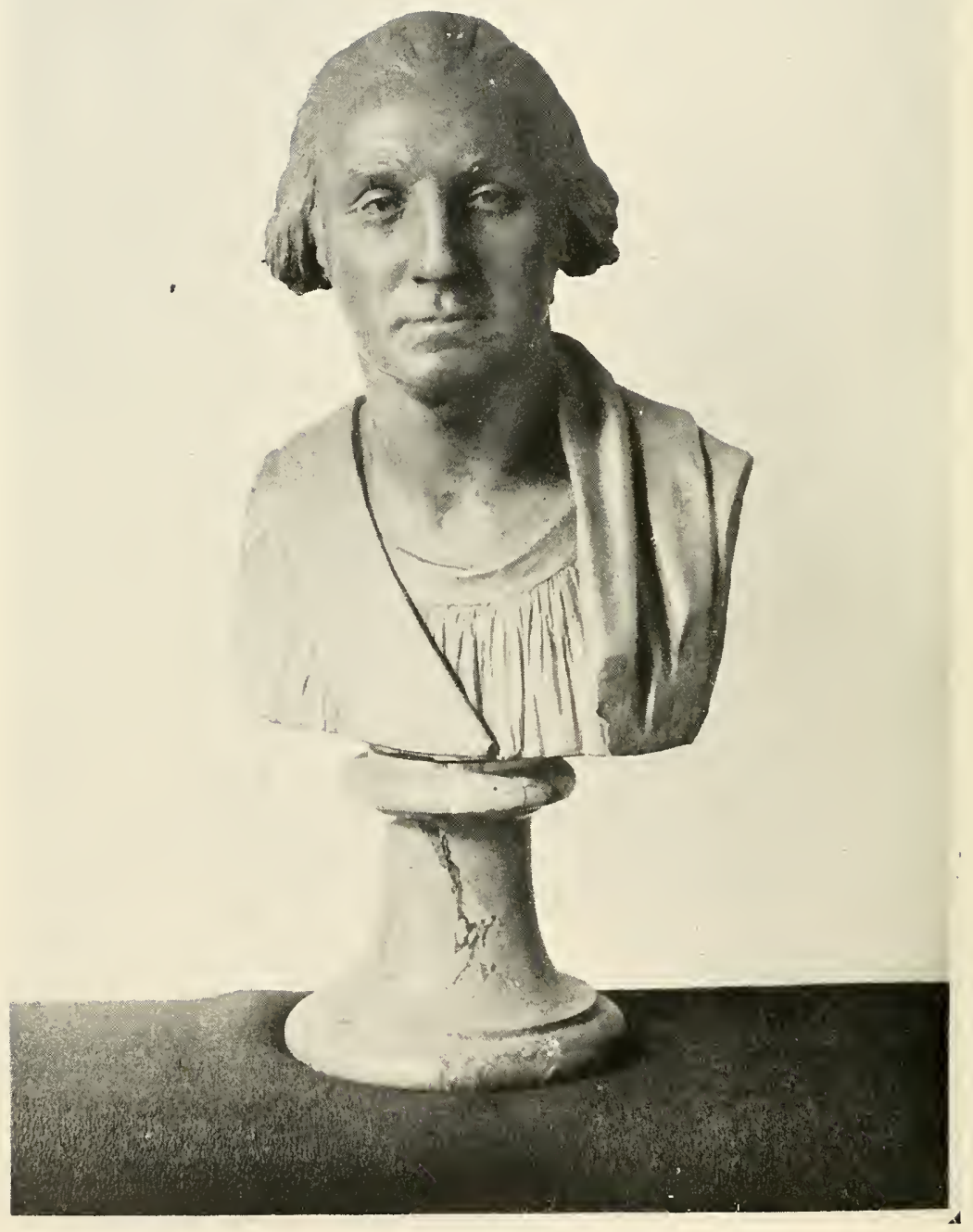

George Wasuington.

See No. irs. 
261 Circular ivory snuff box, gilt rimmed; lined with tortoiseshell; on the lid portrait of La Fayette in colour print. He is reprsented full bust, in uniform, directed to right. About $\mathrm{I}_{7} 89$. Diameter 2 I 2 inches. Fr. 150-

262 Circular candle wood snuff box, gilt rimmed, lined with tortoiseshell; on the lid medallion portrait of La Fayette in stipple. He is represented half length, in uniform, directed to right. About i 789 . Diameter 312 inches.

Fr. $100-$

203 Circular veined box wood snuff box, gilt rimmed, lined with tortoiseshell: on the lid portrait of La Fayette in stipple, printed in colours. He is reprented full bust, in uniform, profile to right. About r790. Diameter 3 I 4 inches.

lir. I 50

204 Circular ivory snuff box, gilt rimmed, lined with tortoiseshell; on the lid beautiful aquatint, printed in colours, representing Louis XVI and La Fayette facing each other. About r 780 . Diameter, 3 I 8 inches. Fr. $200-$ The engraving is probably by Janinet.

265 Circular tortoiseshell snuff box, gilt rimmed; on the lid stipple engraving printed in colours, representing La Fayette, Mirabeau, Bailly, Necker and other revolutionary men inmidst of assignats, Father Time with his scrthe flying over them. About 1790. Diameter $31 / 4$ inches.

$\mathrm{F}_{1}$. $100-$ -

266 Circular tortoiseshell snuff box, gilt rimmed; outside the lid is a revolutionary caricature in aquatint relating to La Fayette, inscribed "D'Animaux Malfaisants c'étoit un très bon plat": with a false bottom containing a licentious caricature, also in aquatint, relating to Queen Marie Antoinette and Bailly. About r790. Diameter 338 inches.

Fr. 200

207 Circular ivory snuff box, lined with tortoiseshell, gilt rimmed; on the lid a revolutionary caricature, aquatint in colours, relating to La Fayette and Queen Marie Antoinette. The former is represented with the body of a cock and the queen with that of a hen. About I 89 . Diameter 31,2 inches.

Fr. 200 
268 Circular tortoiseshell snuff box, gilt rimmed; on the lid and on the bottom are revolutionary caricatures relating to General La Fayette. On one he is represented with the body of a horse and on the other he is trying to catch a marshal's baton. About i789. Diame ter 3 I $/ 8$ inches.

Fr. I 75 -

269 Circular mahagony snuff box, gilt rimmed; on the lid revolutionary caricature in aquatint inscribed "Le Sans Tort" and representing La Fayette. About i789. Diameter $3 \mathrm{r} / 2$ inches.

Fr. Ioo -

270 Circular box wood snuff box, gilt rimmed; on the lid a portrait of La Fayette in aquatint printed in colours. He is represented full bust in uniform, profile to left. About I790. Diameter 2 I $S$ inches. Fr. Ioo-

271 Circular veined box wood snuff box, lined with tortoiseshell, gilt rimmed; on the lid revolutionary engraving representing La Fayette, Dumouriez and Pichegru, surrounded by burning torches and serpents. About 1796. Diameter $37 / 16$ inches. Fr. Ioo-

272 Circular bronze snuff box; on the top portraits of La Fayette and Gerard and on the bottom the "Grenadier de l'ile d'Elbe". About I8I4. Diameter 3 inches.

Fr. $50-$

273 Circular ivory snuff box, gilt rinumed; on the lid relief portrait of La Fayette stamped on cardboard, head in profile to left, white on brown ground. About 1825 . Diameter $2 \mathrm{I} / 4$ inches.

Fr. $60-$

274 Circular snuff box of pressed wood; on the lid relief portrait of La Fayette, surmounted by the 13 American stars. About r825. Diameter 3 inches. Fr. roo-

275 Circular box wood snuff box, gilt rimmed, lined with tortoiseshell; on the lid relief portrait of La Fayette stamped on card board. White on blue ground. About I825. Diameter 3 inches.

Fr. $80-$

276 Circular snuff box of horn; on the lid medallion portrait portrait of General La Fayette in bronze repoussé. About 1825 . Diameter 2 I/2 inches Fr. $80-$ 
277 Circular tortoiseshell snuff box, portrait of La Fayette in bronze d'or repoussé. Full bust in uniform, profile to right. 1830 . Diameter 2 I/2 inches. Fr. $150-$

278 Circular tortoiseshell snuff box, gilt rimmed; on the lid medaillion portrait of La Fayette in bronze d'or repoussé. Bust in uniform, profile to right. "I $789-1830$ " Diameter 3 I'z inches.

Fr. 75 -

279 Circular horn snuff box; on the lid medallion portrait of La Fayette in bronze d'or repoussé. About 1830. Diameter $31 / 4$ inches.

Fr. $75-$

2So Circular bonbonnière of cardboard, gilt rimmed; on the lid picture on glass representing bust of La Fayette in clouds. About 1830 . Diameter 234 inches.

2SI Circular lacquer snuff box; on the lid coloured engraving representing Louis Philippe and La Fayette reviewing the Garde Nationale; on the bottom full descriptive text. About $1 \$_{30}$. Diameter $31 / 2$ inches

Fr. $50-$

$2 \mathrm{~S}_{2}$ Bonbonnière of cardboard, gilt metal rims; on the lid picture on glass representing General La Fayette. He is represented full bust in uniform to right, in clouds. About is30. Diameter 634 inches. Fr. I20-

283 Circular tortoiseshell snuff box, gilt rimmed; miniature portrait of Comte d'Estaing, the Frencl admiral, painted on mother of pearl and inlaid with gold. About I782. Diameter 21516 inches.

Fr. $500-$

A beautiful work of art.

${ }_{2} \mathrm{~S}_{4}$ Circular snuff box of ivory, gilt rimmed; inside lined with tortoiseshell; on the lid medallion portrait of John Paul Jones. stamped on cardboard., white on blue ground. About. ISI5. Diameter $2 \mathrm{I} / S$ inches Fr. So -

28 ; Circular box wood snuff box; on the lid small aquatint printed in colours, portrait of Louis XVI. About 1789 . Diameter 23 '16 inches.

Fr. $50-$ 
286 Etui of pressed wood for minature; on both sides of the lid American emblems round a scroll inscribed Constitution and the laws", the whole in relief. Inside is a miniature of a gentleman. About 1820 . 3 by $21 / 2$ inches.

Fr. 60 - -

287 Circular box wood snuff box, gilt rimmed; outside the lid is the representation of "The U.S. Frigate United States, Stephen Decatur commander, capturing the B. M.'s. Frigate Macedonian, October $25^{\text {th }} 1812$ ", and inside the box, "The U.S. Frigate Constitution, Isaac Hull commander, capturing His B. M.'s Frigate Guerriere, August ig th isiz". Two circular coloured engravings. Diameter $33 / 4$ inches. Fr. $200-$

288 Circular bonbonnière of cardboard, gilt rimmed; on the top is a representation of the "Engagement between the American Frigate The Constitution and the English Frigate The Guerrière"; on the bottom is is the representation of another sea fight of the AngloAmerican war of $18 \mathrm{I} 2$ to I8I4. Two beautiful colour prints. Inside the box are the portraits of Washington and La Fayette in stipple. Diameter 3 5/8.inches.

Fr. $200-$

289 Circular bonbonnière of cardboard, gilt rimmed of the time of the First Empire with representations of portraits of Washington and Napoleon, scenes in the Anglo-American war of 18 I 2 to 18 I 5 and the Napoleon wars. French work of art. Diameter 3 i/8 inches.

Fr. $2.500-$

This beautiful and unique bibelot is the only specimen having come under my observation. The upper lid of the box contains a full length portrait of George Washington and the lower part a full length portrait of Napoleon, both engraved in stipple and delicately printed in colours. The plates are attributed to Madame Cécile Marchand. The inside of the box contains 26 water colour drawings and colour prints on ${ }_{13}$ leaflets (one on each side). These represent $i_{3}$ scenes from the Anglo-American war of $1812-1815$ and 13 scenes of Napoeonic battles.

290 Photographic facsimile. Fr. $3-$ 


\title{
OLD ENAMELS
}

\section{CLOCKS, WATCHES, LETTER WEIGHTS,}

\author{
CUPS, PLATES, PLAQUES, SEALS
}

\section{AND OTHER OBJECTS OF ART \\ RELATING TO AMERICA}

291 Pair of coloured oval enamels representing portraits of Washington and Franklin: the former, bust to right head slightly to left, in uniform with cocked hat, the latter, bust to left, spectacles and fur cap. About 1778 . I $3 / 4$ by $1 \mathrm{I} / 4$ inches.

Fr. $400-$

292 Pair of oval enamels in black and white, gilt rimmed, same subjects as previous. Nounted as supports for a looking glass. About ${ }_{777} \mathrm{~S}$. Height of the enamels 2 inches.

Fr. $400-$

293 Pair of oval enamels in black and white, gilt rimmed, representing portraits of General Reed and Governor Morris, 1778. Mounted as supports for a looking glass. Height of the enamels 2 inches.

Fr. $300-$ One (Reed) is slightly faulty.

294 Pair of circular enamels in black and white, gilt rimmed, representing portraits of George Washington and General Reed. Nounted as supports for a looking glass. About 1778. Diameter of the enamels i $7: 8$ inches.

Fr. $400-$

295 Enamel medallion portrait of Abraham Lincoln in black and white. Ebony frame. Size, without frame, $23 / 4$ inches.

Fr. $20-$ 
296 Gilt bronze clock with the representation of Benjamin Franklin sitting by the trunk of a tree, right hand holding stick and left a book. First quarter of the igth century. Height $14 \mathrm{I} / 4$ inches.

Fr. $400-$

297 Three eigteenth century silver watches with portraits of La Fayette, Franklin and Washington engraved on the lid.

Each, Fr. 50 -

298 Paperweight of green marble with relief portrait of Benjamin Franklin in bronze. He is represented full bust in profile to right. 4 r/ 8 by $32 / 8$ inches. Fr. $150-$

299 Steel paperweight with portrait in bas relief of Benjamin Franklin. About 1800.2 1 $1 / 16$ by i $13 / 16$ inches.

Originally used for stamping purposes.

Fr. IOO -

300 Oval steel paperweight with portrait in bas relief of President Ch. Taylor, 1849. $21 / 2$ by $2 \mathrm{I} / 4$ inches.

Fr. 50 -

Probably intented for stamping purposes.

301 Cup with lid in old Saxe with portrait of George Washington. He is represented full face, in uniform, (Peale type), in a medallion surrounded by oak leaves. On the lid is the picture of a laurel wreatl and a palm branch, the whole painted in brown and gold on white ground. About 1780 . Height 4 I/2 inches. Fr. $800-$

302 China cup and saucer, each with representation of the portrait of General Winfield Scott. Printed in brown on white ground with gold border. About i8r2. Height 3 inches.

Fr. $200-$

303 China cup and saucer, the cup same as foregoing, the saucer with representation of the portrait of Jacob Jones of the U.S. Navy. Painted in brown on white ground with gold border. About I8I2. Fr. I25The cup is somewhat chipped.

304 China plate with representation of General La Fayette presenting King Louis Philippe to the people. With inscription "Voilà le Roi qui nous fallait, c'est la meilleure des républiques." I\$30. Diameter 8 inches.

Fr. $30-$ 
305 Pitcher in white porcelain with relief pictures, repreting the American arms, Washington taking leave of his mother and a full length portrait of Washington. First half of the $\mathrm{ro}$ th century. Height $9 \mathrm{I} / 2$ inches.

Fr. 50

306 Bronze plaque with represəntation in relief of Lord Cornwallis' surrender to Washington at Yorktown. Beautiful work of art, delicately chased. In fine gilt bronze frame of the time of the first Empire. 5 by 3 inches.

307 The same. In "fonte de Berlin."

Fr. $150-$

$307^{A}$ Plaque in bronze repousse with relief portrait of Captain James Cook. He is represented full bust in profile to right. About 1790.16 by 1134 inches.

Fr. So -

308 Plaque in bronze repoussé representing Washington's last interview with his mother. By Rither. Signed and dated, "I800". Old carved gilt frame. $233 / 4$ by I $6 \mathrm{r} / 2$ inches.

Fr. $600-$

309 Photrgraphic facsimile. Fr. $2-$

310 Circular plaque in bronze repoussé with relief portrait of Benjamin Franklin. He is represented full bust, to right, in coat trimmed with fur. Signed "A. Anno". End of the is th century or beginning of ig th. Diameter 22 I 4 inches.

Fr. $600-$

311 Shield in bronze repousse with representation of the 13 American stars within an escutcheon surrounded by war emblems. About i790. Height 5 inches.

Fr. 30

3 I2 American Eagle in steel for bookbinding purposes. About 1800.2 I 2 by 3 inches.

Fr. $75-$

313 American Eagle in bronze, beautifully chased. About I8oo. 4 by $31 / 2$ inches.

Fr. $40-$

314 Old circular bronze seal with monogram "D.S. M.", surmounted by the American eagle. About 1800. Diameter $13 / 8$ inches.

Fr. $15-$ 
315 Octagonal red agate with portrait of Benjamin Franklin in bas relief, probably intented for a ring. Beginning of the I 9 th century. Height $3 / 4$ inch.

Fr. $50-$

3 I 6 Breloque (Seals) in gilt bronze with two red stones, one with the engraving of a portrait of La Fayette, the other with the inscription "Laf". About 1825 .

Curious La Fayette relique.

Fr. So -

3I 7 Miniature portrait of La Fayette, moulded between glass. He is represented half length, in civilian dress, directed to right. In colours. About 1825 . Height $1 \mathrm{I} / 2$ inches.

Fr. $25-$

3 I 8 old razor of pressed horn. On one side are represented in relief the busts of Wasgington and Captain Preble and the American Eagle surmounted by the I3 stars, on the other side, the buts of Voltaire and Montesquieu. About 1805 .

Fr. So -

3I9 Old pocket knife of pressed horn. One one side is represented in relief a full length portrait of Washington, and on the other the American Eagle. About I790.

Fr. $50-$

320 Ivory cover for small book with circular medallion portraits in relief of Benjamin Franklin and Montyon. About I 8 I5. $3 \mathrm{I} / 2$ by 2 inches.

Fr. I $50-$

32 I Ivory cover for small book with circular medallion portrait in relief of George Washington (Dupré type), all carved in one. About $1815.3 \mathrm{I} / 2$ by 2 inches.

Fr. I 50 --

322 Masonic walking stick, made of the root of a tree. The handle is represented by a hand holding a nail of ivory. On the stick itself are carved in relief representations of George Washington, "The Cause of Liberty", snakes, lions, dogs, aligators, masonic inscriptions, etc. About 1790. Height $361 / 2$ inches.

Fr. $250-$ Curious Washington relic. 


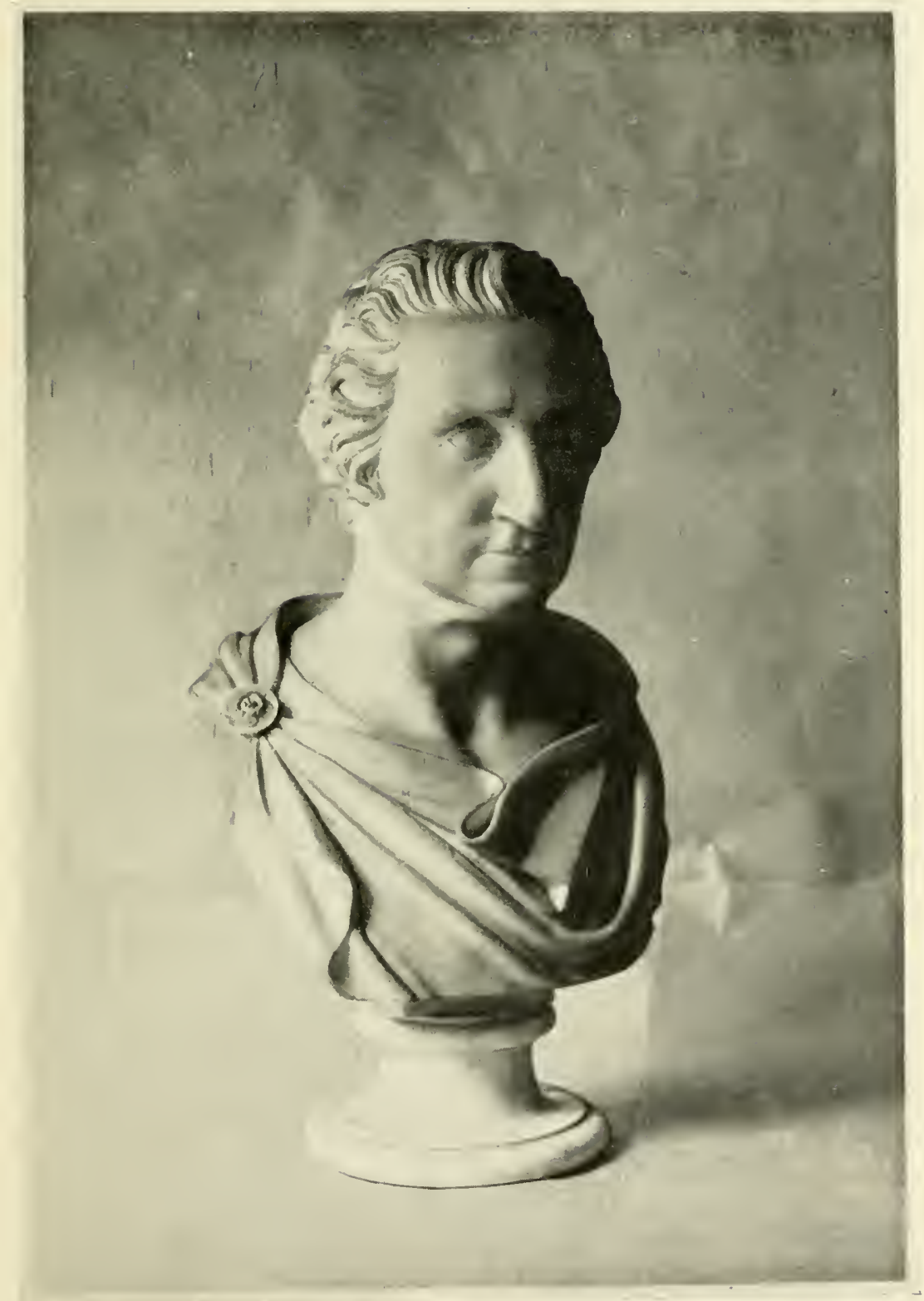

George Washington.

See No. 133. 


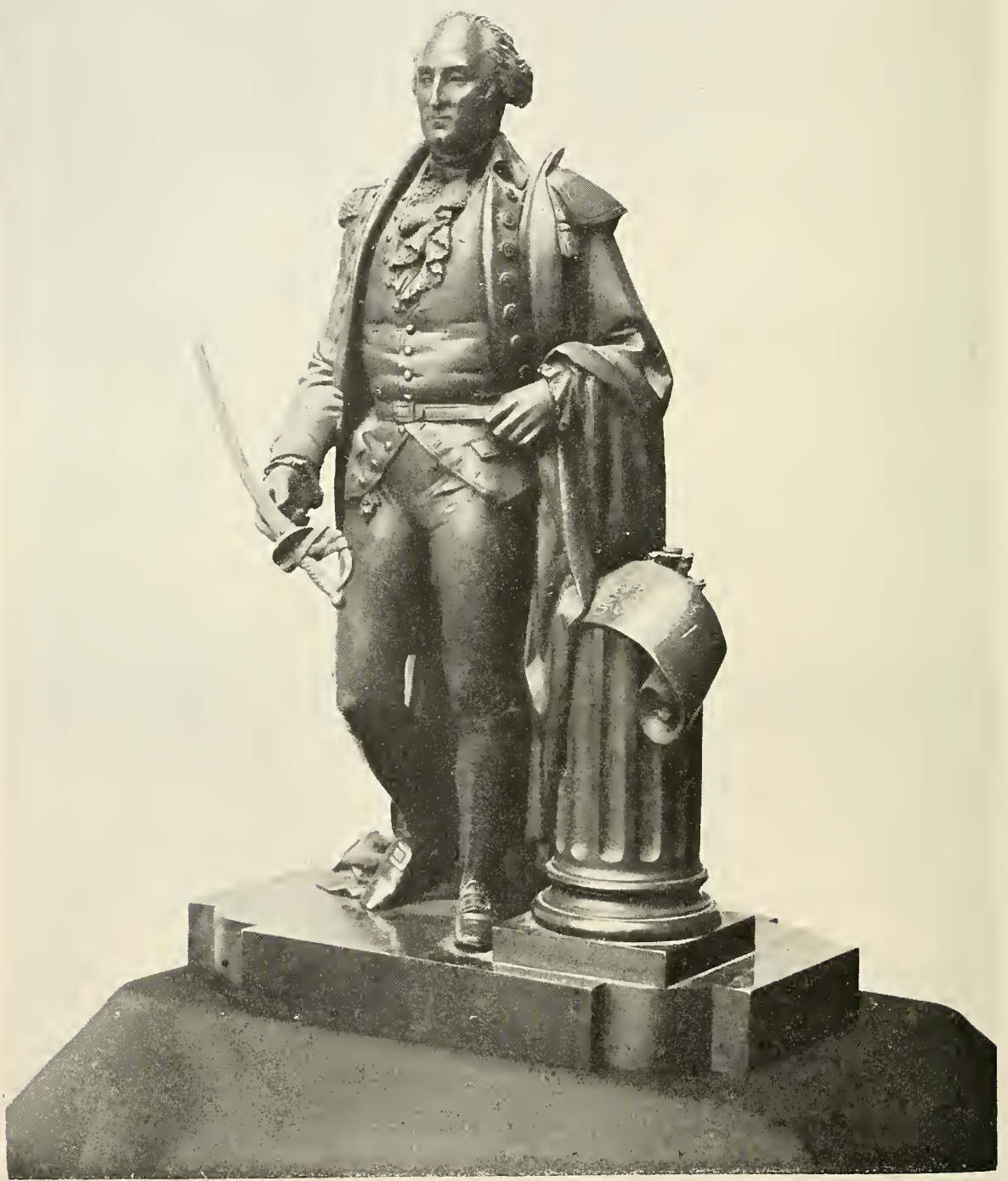

Georce Washington.

See No. I 22. 
323 Work in zinc representing in relief the coat of arms of Benjamin Franklin, surrounded by laurel branches and surmounted by a Greek temple. Oval gilt bronze frame. About I 7 So. $13: 4$ by I I/2 inches. Fr. $60-$

324 Old tapestry representing full length portrait of George Washington, after Stuart. (The Landsdowne portrait). About i790. In an old gilt carved frame. Size (without frame), 18 by 24 inches.

Fr. I.SoO -

Beautifull tapestry work, probably French, of the most perfect conservation and of bright and vivid colours. See illustration.

325 Circular colour engraving representing Franklin, Rousseau and Voltaire. About 1780 . Square gilt rimmed ebony frame. Diameter 23,4 inches.

Fr. So -

326 The same. With circular old gilt carved frame. Fr. So -

327 Circular colour engraving, portrait of La Fayette in the uniform of a commander of the Garde Nationale, i 789 . In stipple, printed in colours. Old gilt carved frame. Diameter 3 I/2 inches.

Fr. $50-$

328 Circular colour engraving representing the portraits of La Fayette and Louis XVI, face to face. Old gilt carved frame. About 1789 . Diameter $33 / 4$ inches.

Fr. $80-$ 


\section{OLD MEDALS RELATING TO AMERICA}

329 " J. L. Ackington 1791 ". Reverse: "Cheapest booksellers in the world". Diameter I I/8 inches. Fr. 4 -

330 "Washington Allston". Reverse: "American Art Union 1847 ". C. C. Wright sc. In copper. Diameter, $2 \mathrm{I} / 2$ inches.

Fr. $40-$

33 I "John Bell, Union candidate for the presidency, 1860 ". In copper. Diameter I $1 / 16$ inches. Fr. 4 -

332 "Daniel Ball and Co. Grand Rapids, Mich.". In copper.

Fr. 3 -

333 "John Brown. Nè à Torrington, le 9 Mai 1800. J. Winden". Reverse: "A la mémoire de John Brown assassiné juridiquement à Charlestown, le 2 Décembre $1859 \ldots$. .. In copper. Diameter 2 r/4 inches.

Fr. 15 -

334 "Henry Clay, Born April 12 1777. Died June 291852 ". Reverse: "The eloquent defender of national rights and national independence". In box wood. Diameter 3 inches. Fr. So-

335 "Henry Clay and the American system". Reverse: "United we stand". In copper. Diameter I $1 / 16$ inches. 
336 " Henry Clay". Reverse: "Clay, Frelinghuysen, Protection, Union". Gilt bronze. Diameter I inch.

Fr. 5 -

337 "Cleveland President". Reverse: "City of Chicago, incorporated 4 th March 1837 ". In white metal I I/2 inches. With ring.

338 The same. Smaller size. I I 8 inches.

Fr. 4 -

Fr. 3 -

339 "Souvenir of S. E. Cody Jr. Texas." In copper. Mounted as a pin. Diameter I I/4 inches.

Fr. 4 -

340 "Christophorus Colombo. Petit F.". Reverse: "Natus An 1442. Obiit In Valle Oleti apud Hispanos An 1506. Durand edidit IS2I". In copper. Diameter I $5 / 8$ inches.

Fr. 5 -

34 I "Cristobal Colon". Reverse: "Union Ibero-Americanae. Madrid. Fundada el 25 Enero di 1885 ". In copper. Diameter I 58 inches. Fr. 5 -

342 Christopher Columbus. Collection of 4 I beautiful medals in copper, white metal and silver, struck in commemoration of the fourth aniversary of the discovery of America by Columbus and of the Columbian fair, held in Chicago, 1893 .

The lot, Fr. $150-$

343 "Don Ferdinando Cortes 1529. Anno etatis 37". Reverse: "Ivdic. M. Dni apprehendit, eos et Fortitvdo, eivscorrobaravit brachivm mevm". In copper. Diameter $21 / 4$ inches.

Fr. $100-$

344 "Hernand Cortes. Vivier F.". Reverse: "Natus Metallini in Hispania An. ${ }_{1485}$. Obiit An 1551. Durand Edidit". In copper. Diameter I $5 / 8$ inches. Fr. 5 -

345 The same. With another reverse. "Cuivre". Fr. 3 -

346 Wilh. Crul Toparcha Burgst Praef. Class Holl. et W.F." Reverse: "Pugna occub. IV Feb. 178I". (Naval action off Curaçao). In silver. Diameter I $7 / 8$ inches.

Fr. $50-$

347 Benjamin Franklin. By Aug. Dupré. In copper I 7/8 inches. Re-struck. (Loubat 15.) Fr. 3 - 
348 Benjamin Franklin. By Aug. Dupré. In copper. I 7/8 inches. (Loubat I6.)

Fr. $25-$

349 The same. In gilt bronze. Very fine.

Fr. $40-$

350 The same. Proof impression, in bronze. Without reverse.

Fr. $20-$

35 I The same. Re-struck.

Fr. $3-$

352 "Benjaminus Franklin. Godel sc.". Reverse: "Natus an 1706 Bostoniae in America Foederata. Obiit An I 790. Series Numismatica I8I9. Durand edidit.". Diameter I $5 / 8$ inches.

Fr. 5 -

353 "Franklin. Bienfaisance du Génie. Monthyon, Génie de la Bienfaisance". Barré sc. I833. In copper. I 5/8 inches.

Fr. IO -

354 Major General Horatio Gates. (Surrender of the British Army at Saratoga.) "Horatio Gates duci strenuo Comitia Americana ". Reverse: "Salus regionum septentrional". By N. Gatteaux. In copper. Diameter 2 3/16 inches. (Loubat 2.) Fr. 45 -

355 The same. Proof impression without reverse. In zinc. Fr. $40-$

356 " Ulysse S. Grant". Reverse : "Struck and distributed... Dec. I6. I879". In copper. I inch. Fr. 3 -

357 "Winfield S. Hancock". Reverse: "Democratic canditate I880". In white metal. Diameter $3 / 4$ inch.

Fr. 3

358 "Maj. Gen. W. Harrison. Born Feb. 9. I778". Reverse: "The People's choice. The Hero of Tipperanoe". In zinc. Diameter $1 \mathrm{I} / 2$ inches. Fr. $30-$

359 "Gen. Benjamin Harrison, 1888 ". Reverse: "Republican candidate". In copper. Diameter $7 / 8$ inch.

Fr. 3 -

360 "Jackson". Reverse: "Andrew Jackson the stern old soldier, a foe to traitors. 7 th President U. S.". In white metal. Diameter, I inch.

Fr. 5

36I "James Garfield". Reverse: "For the civic wreath". In white metal. Diameter I I/I6 inches. Fr. 4 - 
362 Lieutenant-Colonel John Eager Howard (Victory of the Compens). " Joh. Egar Howard legionis peditum praefecto Comitia Americana". Reverse: "Quod in nutantem hostium aciem, etc.". By Duvivier. In silver. Diameter i $7 \mathrm{~S}$ inches (Loubat ro). Fr. $125-$ 363 The same. In copper.

Fr. $45-$

364 " Lieut. General T. J. Jackson, Stonewall. Born 1821 Died 1863. Caqué F.". Reverse: "Kernstown, Front-Royal, Middletown, Winchester, Strasburg, Harrisonburg, Port-Republic, Mechanicsville, Gold Harbour, White Oak Swamp, Malvern Hill, Cedar Mountain, etc.". In copper. Diameter 2 inches.

Fr. $25-$

365 Captain John Paul Jones (Capture of the Serapis). By Dupré. In copper. Diameter $23 / 16$ inches. (Loubat 5 .)

360 The same. Re-struck.

Fr. $25-$

Fr. $3-$

367 "Thaddeus Kosciuszko. Caunois F." Reverse: "Natus An I744 Stechnowicz Ducat-Lithaviae in Polonia. Obiit an. I8I7. Séries numismatica ISIS. Durand édidit." Diameter i $5 / 8$ inches.

Fr. $S$

368 "Marquis de Lafayette Command. gl de la Garde Nationale (1789)." No reverse. In copper. Diameter 2 inches.

Fr. 15 -

369 " Le général Lafayette. Né en septembre 1757, commandant de la Garde Nationale Parisienne en 1789". Reverse: "Objet tour à tour d'idolatrie et de haine on ne se rapelle aujourd'huy que ses malheurs et les services qu'il a rendus à la liberté des deux mondes." By Lienard, an 9(ISor). In silver, Diameter $12 / 8$ inches.

Fr. 45 -

370 The same. In copper.

Fr. $10-$

37 I The same. Re-struck.

Fr. 2 -

372 "M. de La Fayette, Maréchal de camp, com. gén. de la Garde Nationale Parisienne." Reverse: "Comp. de Grena diers volontaires du $3^{\circ}$ bataillon, $6^{\circ}$ division, I $7 S_{9}$."

Octagon. Dumarest F, In silver.

Fr. $45-$ 
"M. P. J. R. J. G. Motier, Marquis de La Fayette. Né le 6 sept. I757. Offert par B. Duvivier à la Garde Nationale." Reverse: "Vengeur de la liberté dans les deux mondes, I 789 ." In silver. Diameter I $5 / 8$ inches.

Fr. $60-$

374 The same. In copper.

Fr. $15-$

375 " Le général Lafayette. Né à Chavaniac le 6 oct. I757." Reverse : "Havre, 5 octobre 1825. Brandywine Tellus Vedit etc.". In plated copper. Diameter 2 inches.

Fr. $30-$

376 "Général Lafayette". Reverse: "The Defender of American and French Liberty, I777-1824. Born in Chavaniac the 6 september 1757 ". In copper. Diameter I $13 / 16$ inches.

Fr. Io -

377 (La Fayette). "I789-1830. E. Gatteaux". Reverse: "A. Lafayette. L'Arrondissement de Meaux, Juillet I830". In copper. Diameter 2 inches.

Fr. $20-$

378 (La Fayette). "I789-1830". Reverse: "Garde Nationale de Dunkerque". In copper. Diameter I I/16 inches.

Fr. 4 -

379 "Général Lafayette. Gloire aux défenseurs de la Patrie, 28-29 juillet 830 ". Reverse: "Vive Louis-Philippe d'Orléans". In zinc. With tricolore ribbon. Diameter I 9/16 inches.

Fr. Io -

380 "Le Général Lafayette. Né à Chavaniac le 6 octob. 1757. Caunois F." Reverse: "Appelé par le vœu unanime des citoyens au commandement général des Gardes Nationales, le 28 juillet 1830 ". In copper. Diameter 2 inches.

Fr. I2 -

381 (La Fayette). “ I789-I 830 ”. Reverse: “Banquet offert au Général La Fayette, I6 sept. I830". In copper. Diameter I I/r 6 inches.

Fr. 4 -

382 "La Fayette, Général en chef." Reverse: " Io Légion. Lemercier Col., etc.". In copper. Diameter I I/I6 inches.

Fr. 4 -

383 "Général La Fayette." Reverse: “L'Ami de genre humain". In copper $(1830) .7 / 8$ inch. Fr. $4-$ 
384 "Lafayette Vétéran de la Liberté. Aux intrépides citoyens de Paris. Barricades des 27, 28, 29 Juillet I830." In copper. Diameter I $1 / 8$ inches. Fr. 4 -

385 (La Fayette.) "Liberati Non Defuit Unquam. W. Oleszczynski F.". Reverse: "Paolo J. R. Lafayette Polonia Meerens. Obiit 20 Maii 1834 ". In copper. Diameter 2 inches. Fr. 25 -

386 "Hon. Abraham Lincoln, 1860." Reverse: "The rail splitter of the West". Gilt bronze. Diameter I $1 / 8$ inches.

Fr. 5 -

387 " Abr. Lincoln Rep. Candidate for President 1860." Reverse : "Protection to American Industry". In copper. Diameter I 1/16 inches.

Fr. 6

388 "Abraham Lincoln President of the United States. Hugues Bovi." Reverse: "Emancipation of Slavery proclamed. September 22, 1862 ". In copper. Diameter $13 / 8$ inches.

Fr. $20-$

389 The same. Mounted in a gilt rimmed frame, surmounted by the American eagle.

Fr. $30-$

390" Abraham Lincoln, 1865." Reverse: "His memory is enshrined in every loyal heart". In silver. Diameter I $3 / 4$ inches.

Fr. 6 -

39 I Abraham Lincoln. "Dédié par la Démocratie française à Lincoln deux fois élu des Etats-Unis." Reverse : "Lincoln l'honnête homme abolit l'esclavage, rétablit l'union, sauva la république sans voiler la statue de la liberté. Il fut assassiné le i 4 Avril i 865 ". By FrankyMagniadas. In copper. Diameter 3 1/4 inches.

Fr. $250-$

Of the greatest rarity, only four or five copies known so far.

392 "President Lincoln." Reverse: "Compositions SpielMarke". Gilt bronze, Diameter 1 1/8 inches.

F1. 4 -

393 “ George B. Mc Clellan." Reverse: "The Union must and shall be preserved". In copper. Diameter i inch. 
394 "Maj. Gen. Géo. B. Mc Clellan." Reverse: "Inaugurated Governor of New Jersey, 1878 ". In white metal. Diameter I inch.

Fr. 4 -

395 Brigadier-General Daniel Morgan (Victory of the Cowpens). "Danieli Morgan duci exercitus Comitia Americana.". Reverse : "Victoria libertatis vindex". By Dupré. In copper. Diameter 23/16 inches. (Loubat $S$.

Fr. 45 -

396 The same. Proof impression in zinc. Without the reverse.

Fr. $40-$

397 "Wm. J. Mullen gold dial manufacturer. Established i $82 \mathrm{~S}$. New York." In copper. Diameter I 5/I6 inches.

Fr. 4 -

398 "Neff and Duff." Reverse: "Iron front Austin, Texas". In silver. Diameter I I/S inches.

Fr. 4 -

399 "John Pintard." Reverse: "New York Historical Society. Founded i804. Incorporated I809. Erected $1857 \%$. In copper. Diameter $29 / 16$ inches. Fr. I5 -

400 Major General Peter Buel Porter (Victories of Chippewa, Niagara and Erie). By Fürst. Gilt bronze. Diameter 2 I/2 inches. (Loubat 4I.) Fr. $100-$

401 "Robert Raikes." Reverse: "Sunday school of Thomas Church, New York, I827". In zinc. Diameter I $3 / 8$ inches.

Fr. 8 -

402 "G. B. Rodney." Reverse: "The Glorious memory of the $3 \mathrm{~d}$ of Feb. I78I when he severely punished the "Dutch ...." In copper. Diameter I 5/16 inches.

Fr. $25-$

403 "John Jervis Earl of St. Vincent, Admiral of the White. Born January 26 I735." Reverse: "With 22 ships and $1_{42} 8$ guns defeated the Spanish Fleet, etc." In white metal. Diameter I $7 / 8$ inches. Fr. $30-$

404 "Zachary Taylor, President of the United States, 1849." Reverse: "Peace and friendship". In gilt bronze. Diameter 3 inches. Very rare. (Loubat 65.) Fr. $100-$ 


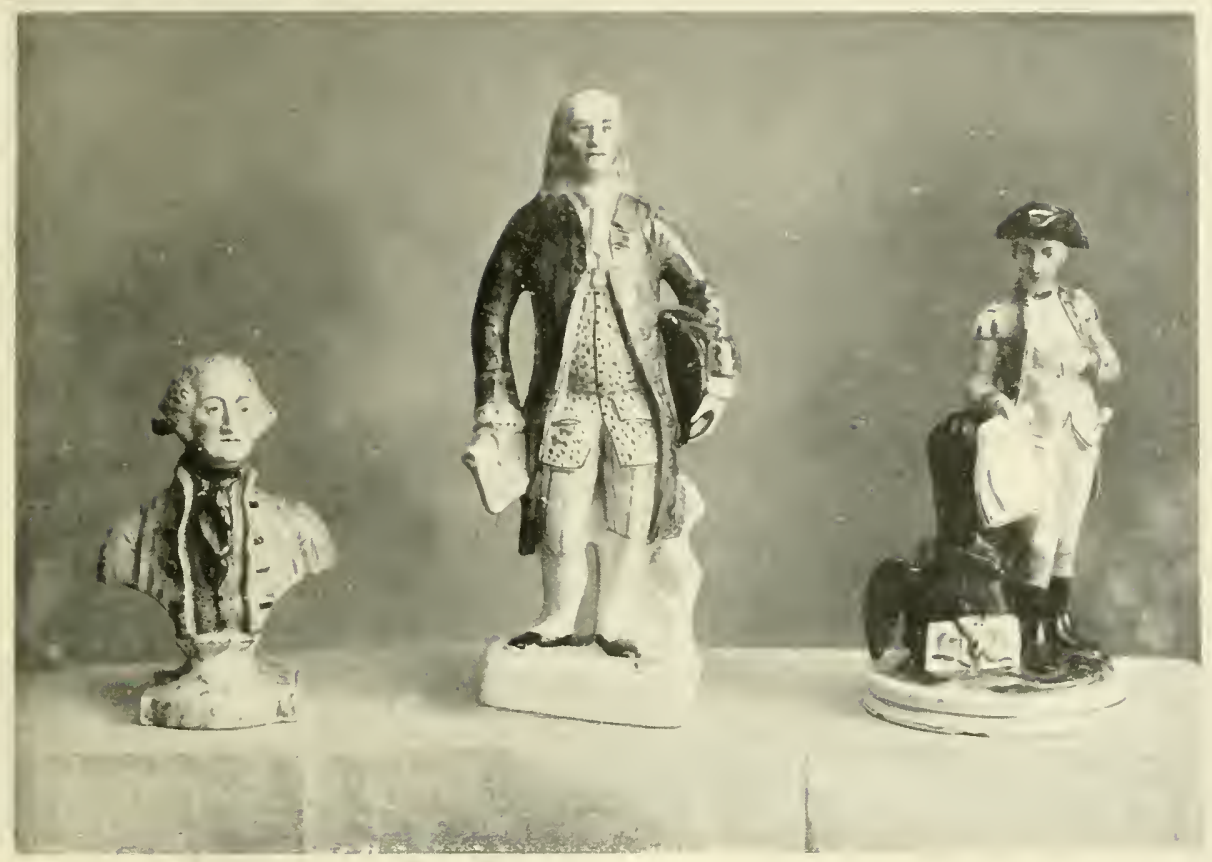

No. 121.

No. 146.

No. 125.

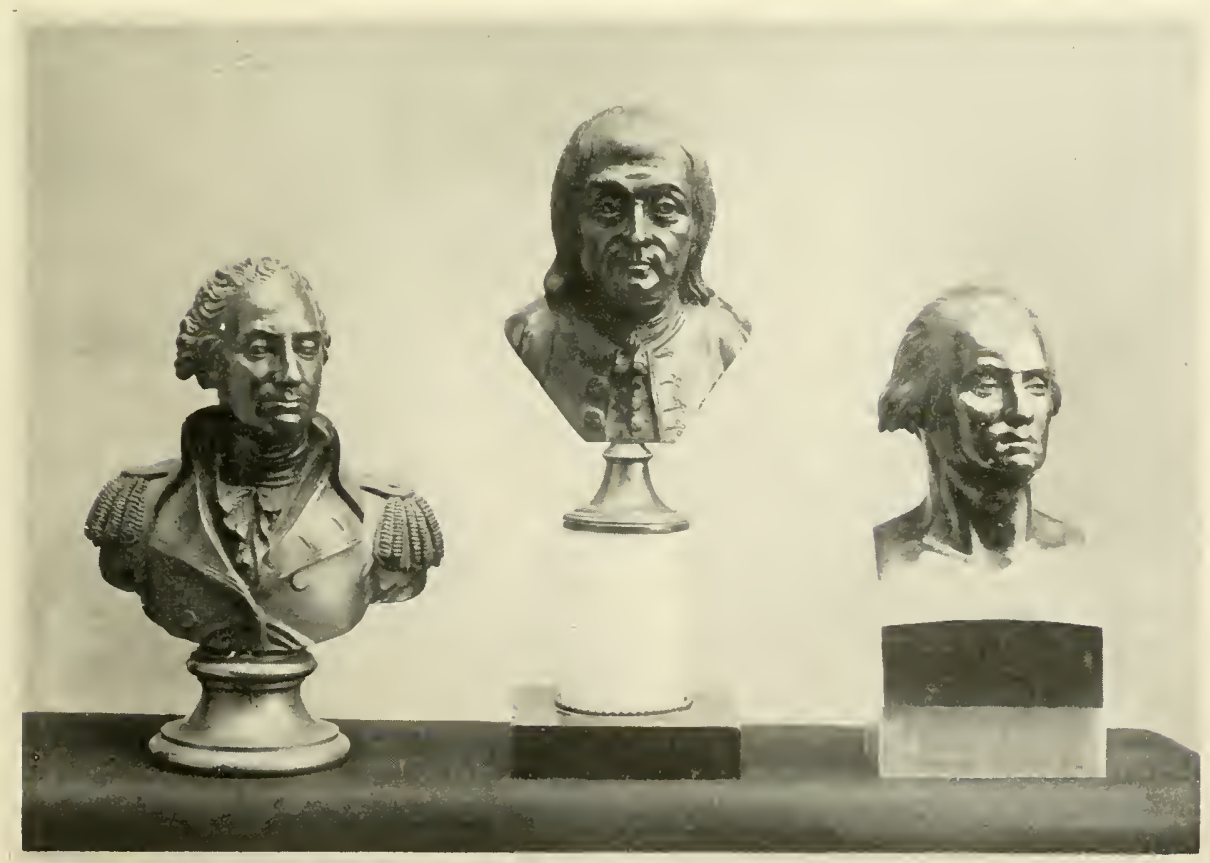




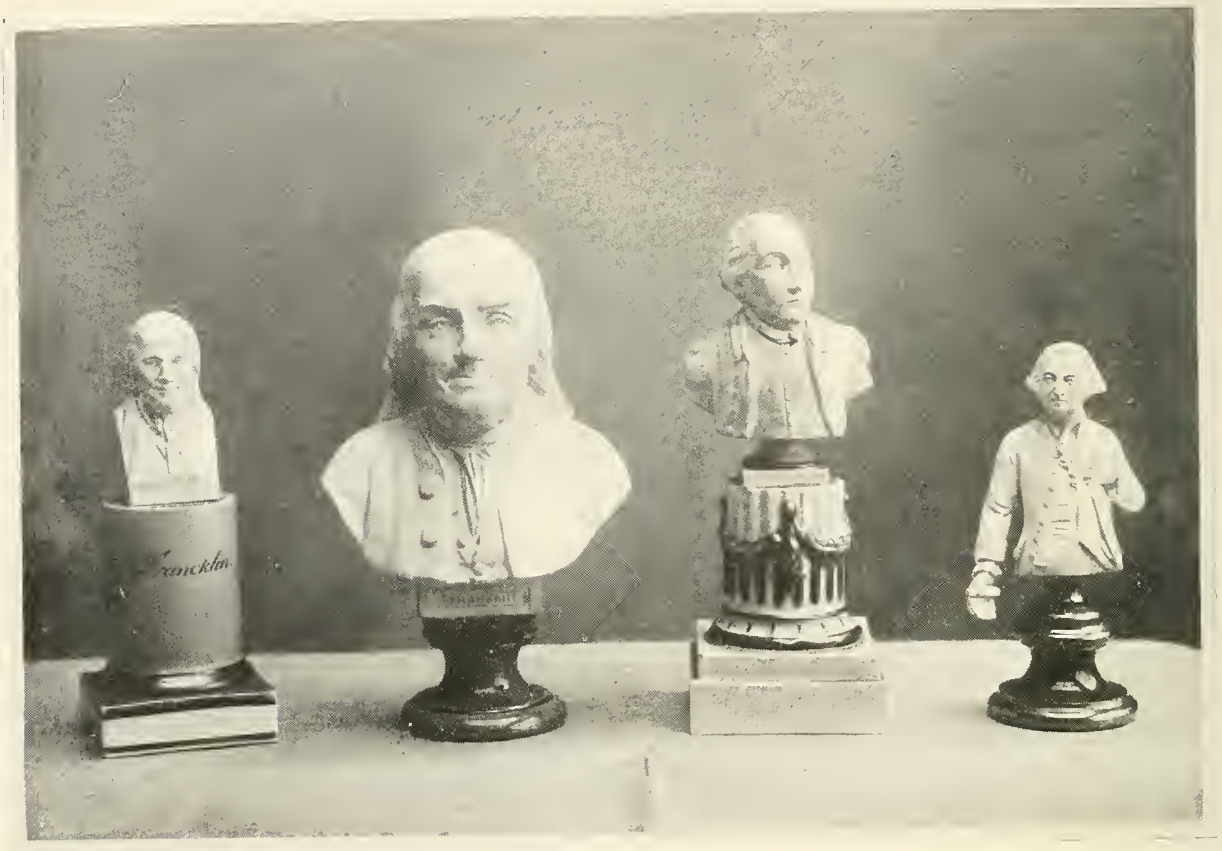

No. 155. No. $164 . \quad$ No. $116 . \quad$ No. 120.

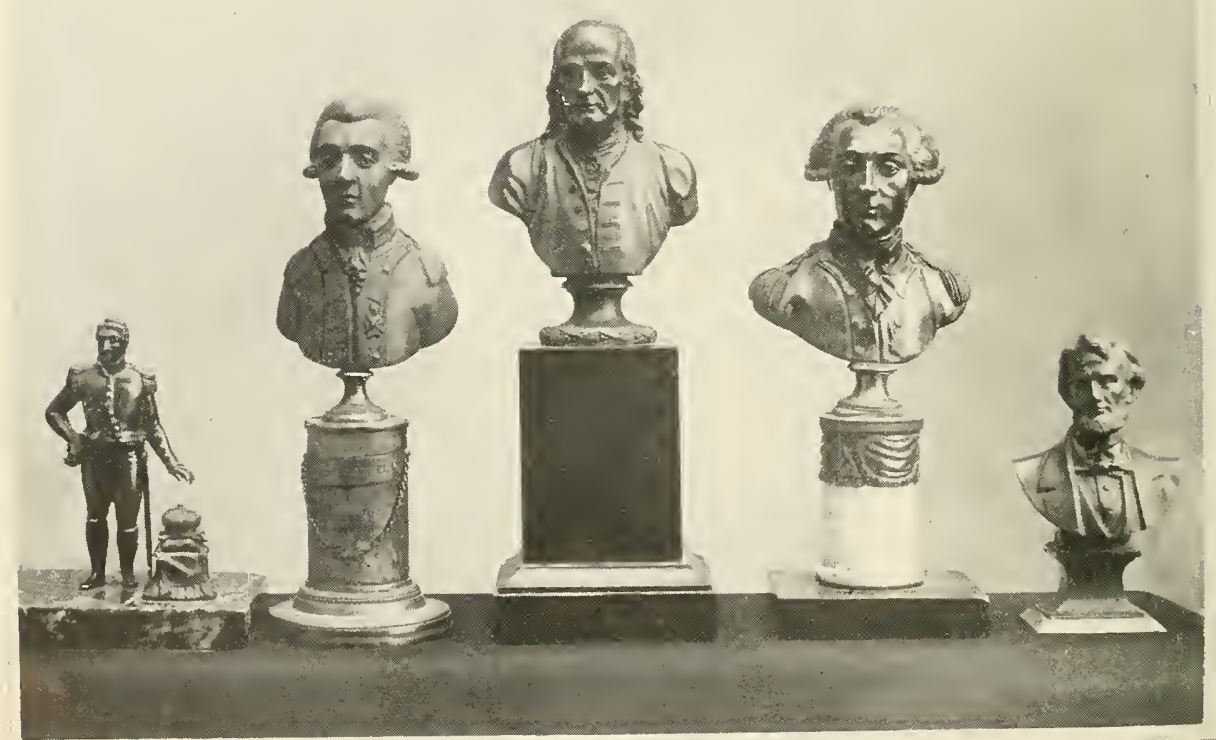

No. 167.

No. 166 .

No, 160.

No. 165.

No. 174 
405 "General Tom Thumb." In copper. Diameter $7 / 8$ inch.

Fr. 4 -

400 Captain Thomas Truxtun (Action with the Vengeance). In copper. Diameter $2 \mathrm{I} / 4$ inches. Before inscription (Loubat 22).

Fr. So -

407 "Gov Gullan C. Verplank our next" Reverse : "A faithful friend to our country." In copper. Diameter I 1 I 6 inches.

Fr. 6 -

408 General George Washington. (Boston retaken). "Georgio Washington svpremo dvci exercitvvm adsertori libertatis Comitia Americana." Reverse: "Hostibus primo fugatis." By Duvivier. In copper. Diameter $23 / 4$ inches. (Loubat I).

Fr. 50 -

409 " G.Washington Pres. Unit. Sta." Reverse: "Commiss. Resigned. Presidency Relinq. I797." In copper. Diameter I 5,8 inches.

Fr. $40-$

410 "Geo Washington. Born Virginia Feb. 11.1732. Reverse: "General of the American Armies 1775. Resigned ${ }_{17} 8_{3}$. President of the United States, ${ }_{77} 8_{2}$. (A. Maney F. 1700). In copper. Diameter $17 / 8$ inches.

Fr. 25

4I " G. Washington $\mathrm{E}^{\mathrm{r}}$ General of the Contin. Army in America." Reverse: "Washin. réunit par un rare assemblage les talents du guerrier et les vertus du sage." In copper. Diameter I 9/16 inches.

Fr. $40-$

4 I 2 The same. In zinc.

Fr. 10

413 "Washington and Independence 1783." Reverse: "United States." In copper. Diameter I I/I6 inches.

Fr. Io -

4I4 "George Washington." Reverse: "Liberty and security " On the rim: "An Asylium for the oppress'd of all nations." In copper. Diameter I $3 / 8$ inches.

Fr. 15 -

4I5 "Georgio Washington. Lauet." Reverse: A palm and oak branch. In copper. With a whole for a ribbon. Diameter I I/2 inches.

Fr. Iо - 
416 "George Washington. Born Feb. 11 1732. Died Dec. 21 1799." Reverse: "Gen. of the American Armies, I775. Resigned the commd. 1783, etc." In white metal. Diameter I 5/16 inches.

417 " George Washington Esq" Late President of the United States of America." Reverse: "With courage and fidelity he defended the rights of a free people. Died Dec. I 4. 1799 aged 68. "Westwood F. Gilt bronze. Diameter I 9/16 inches. Fr. 45 -

418 "George Washington. Ob. 14 Dec" 1799 Ae: 68." Reverse: "The Hero of freedom, the pride of his country and ornament of human nature, I Soo." Gilt bronze. Diameter I $1 / 2$ inches. Fr. $30-$

419. "General Washington. Inscribed to his memory by D: Eccleston Lancaster 1805." Reverse: "He laid the foundation of American liberty in the xvin century, etc." In copper. Diameter 3 inches. Fr. I50-

420 "Georgius Washington. Bacon sculp." Reverse : "Natus Virginiae in America Foederata. An. 1732. Obiit An. 1799 Series Numismatica I8r9. Durand edidit." Diameter I $5 / 8$ inches. Fr. 5 -

421 "Georgius Washington. Vivier sc." Same reverse as foregoing. Diameter I $5 / 8$ inches. Fr. 5 -

422 (George Washington). "Patriae Pater." Reverse : Struck and distributed in civic procession February 22 d. 1832 , the centennial anniversary of the birth day of Washington, by the gold and silver artificers of Philad." In white metal. Diameter I 5/16 inches. Fr. $20-$

423 "Washington, Kosciusczko, Lafayette. To the heros of liberty the friends of the peoples independence." By Logat. Cercle Britannique. Rue Neuve S'-Augustin à Paris. In copper. Diameter 2 inches. Fr. $15-$

424 "Georgio Washington." Reverse: Russian eagle. In copper. Diameter $3 / 4$ inch. Fr. 5 -

425 "George Washington." Reverse: "Success to the United States." In copper. 3/4 inch. Fr. 6 - 
426 (George Washington). Reverse: ' Liberty bell 1776." In silver. Diameter 3,4 inch. Fr. 8 -

427 Lieutenant-Colonel William Augustine Washington.

(Victory of the Cowpens). "Gulielmo Washington legionis equit. praefecto Comitia American." Reverse: "Quod parva militum manu etc." By Duvivier. In copper. Diameter I I3,16 inches. (Loubat 9).

428 The same. In zinc.

429 The same. Re-struck.

430 "Webster." Reverse: "Daniel Webster the able defender of the constitution." By Bolen. In copper. Diameter I inch.

Fr. 4 -

431 "Daniel Webster." Reverse: "R. Hill. dealer in coins. New-York, 1860." In white metal. Diameter I r/8 inches.

Fr. 4 -

432 "Thomas Wildey." Reverse: "National Semi Centennial anniversary of Odd Fellowship held at Philadelphia, April 26. 186.9." In white metal. Diameter $1 \mathrm{r} / 2$ inches.

Fr. 5 -

433 Victory of Carthagena. "Ludovicus xil11. J. MavgerF." Reverse: "Hispanis victis ad Carthaginem Novam. I643. " In copper. Diameter I 5,8 inches. Fr. 12 -

434 Battle off Martinique. "Ludovicus Magnus Rex Christianissimus. Dollin F." Reverse: "Colonia Francorum Americana Victrix, 1664." In copper. Diameter I $5 / 8$ inches.

Fr. I 2 -

435 Conquest of S'-Christopher. "I udovicus xinl Rex Christianissimus I. Mavger F." Reverse: "Colonia Fr. Stabilita Angl. ex Insula St-Christoph. exturbat, 1066. In copper. Diameter i 5,8 inches.

Fr. 12

436 Conquest of Cayenne. "Ludovicus Magnus. J. Mavger F." Reverse : "Cayana Recuperator 1676." In copper. Diameter I $5 / 8$ inches Fr. 12 - 
437 Victory off Tabago. "Ludovicus Magnus... J. Mavger F." Reverse: "Ad Ins. Tabago I677." In copper. Diameter I $5 / 8$ inches.

Fr. I2 -

${ }_{43} S$ Deliverance of Quebec. "Ludovicus Magnus. J. Mavger F." Reverse: "Kebeca Liberata I690." In copper. Diameter I $5 / 8$ inches. $\quad$ Fr. $30-$

439 Surrender of Carthagena. "Ludovicus Magnus. J. Mavger F." Reverse : "Carthago Americana Vi Capta I697." In copper. Diameter I 5/8 inches. Fr. 12 -

440 Victories of the French at Carthagena and Barcelona. "Ludovicus Magnus. J. Mavger F." Reverse: "Victorio Comes Francorum 1697." In copper. Diameter I $5 / 8$ inches.

Fr. ${ }_{2} 2-$

44 I Conquest of Guadeloupe. "Ludovicus xv D. G. Fran et Nav Rex. Du Vivier F." Reverse: "Guadelupa Insula Munita, Philippo Regente, I72I." In copper. Diameter I $5 / \mathrm{S}$ inches.

Fr. 15 -

442 Siege of Porto-Bello. "The British Glory revived by Admiral Vernon." Reverse: "Who took Porto-Bello with six ships only. Nov. 22, 1739." In copper. Diameter I $\mathrm{I} / 2$ inches.

Fr. $20-$

443 Siege of Carthagena. "Admiral Vernon veiwing the town of Carthagena." Reverse: "The Forts of Carthagena destroud by Adm. Vernon, I74I." In copper. Diameter I $\mathrm{I} / 2$ inches. $\quad$ Fr. 15 -

444 Siege of Carthagena. "I came I saw I conquered Carthagena." Reverse: "None more ready non more brave." In copper. Diameter I I/8 inches. Fr. 6 Not in perfect condition.

445 Siege of Carthagena. "The Pride of Spain Humbled by Ad. Vernon and Sir Chal. Ogle." Reverse: "They took Carthagena April I741." In copper. Diameter I I 2 inches.

Fr. 15 -

446 Siege of Carthagena. Beautiful collection of 17 different medals, relating to Admiral Vernon and the Siege of Carthagena. In copper. The lot, Fr. $225-$ Several of the above are exceedingly rare, especially one of oblong size. 
447 "Adm. Boscawen took Cape Breton." Reverse: "Louisbourg. Jul. 20. 1758 ". In copper. Diameter I $5 / 8$ inches.

Fr. $45-$

${ }_{44}$ S Taking of Louisbourg. "Georgius II Rex". Reverse : "Louisbourg Jul. 27. Fronti. Aug. 27. Duquesne Nov. 24. Howe, Boscawen, Amherst, Bradstreet, Forbes, Keppel.... I758". In copper. Diameter 1 II/16 inches.

Fr. $30-$

449 "Quebec taken 1759." Reverse: "Britannia. Wolfe. Saunders". In copper. Diameter I 9/16 inches.

Fr. $40-$

450 "Independence Hall 1776." Reverse: "The Liberty Bell proclaim Liberty throughout the land unto all, the inhabitants thereof. Levitium XXV". In gilt bronze. Diameter i 12 inches.

Fr. 15

45I The same. In white metal.

Fr. 12

452 Battle of Rhode Island, August 1778. "D'Tlugtende Americaanen van Rhode Yland." Reverse: "De Admiraals Flag van Admiraal Howe, r 779 ”. In copper. Diameter I I/4 inches.

Fr. 20

453 Alliance of the United Powers for the cause of the liberty of the American Colonies. "Gewapende Neutraliteit." Reverse: "Jehovah Wreekerder Verbon der staaf Katharinas nulpverdraj... i780". By A v. Baali. In silver. Diameter $11 / 4$ inches. Fr. 60 -

454 Libertas Americana. (Surrender of the British Armies at Saratoga and at Yorktown.) Reverse: "Non sine diis animosus infans". By Dupré. In silver. Diameter I $7 / 8$ inches. (Loubat 14.)

455 The same. In gilt bronze.

Fr. $200-$

456 The same. In copper.

Fr. $75-$

Fr. $45-$

457 The same. Proof impressions in zinc. In two gilt rimmed frames.

Fr. 60 -

458 The same. Reverse only. Proof impression in zinc.

Fr. $25-$

459 The same. With Philadelphia business advertisements on the reverse. Diameter $7 / 8$ inch. Two different types.

Each, Fr. 3 - 
460 Libertas Americana. The original plaster models made by Auguste Dupré. Two large medallions in circular oak frames. Diameters (without the frames) 12 and 15 inches.

The pair, Fr. $3.000-$

These are the original plaster models as they were composed and engraved by A. Dupre after the ideas of Benjamin Franklin, and in reference to them it will be of interest to read the following extract from a letter of Benjamin Franklin to Robert R. Livingston, the secretary for Foreign Affairs, dated "Passy, March $4^{\text {th }} 1782, \ldots$ This puts me in mind of a medal $I$ have had a mind to strike since the late great event (Yorktown) you gave me an account of, representing the U. S. by the figure of an infant Hercules in his cradle; and France by that of Minerva, sitting by as his nurse with her spear and helmet, and her robe specked with a few fleurs-de-lis ".....

See illustration.

462 "Libertas Americana 1783." Reverse: "Commvni Consensv". In zinc. Diameter I $7 / 8$ inches. Fr. $45-$ Very rare.

463 Trealy of Amity and Commerce between the United States of America and the United Netherlands. "Faustissimo foedere jvnctae die VII Octob. 1782." Reverse: "Justitiam et non temnere divvs". By J. G. Holtzhey. In silver. Diameter I 13/16 inches. (Loubat 13.1

Fr. $125-$

404 The same. Smaller size. In silver. Diameter I 5/16 inches.

Fr. 75 -

465 "The United States, Holland and Great Britain." Reverse: "Aan de Staaten van Friesland, etc.". B. C. $\mathrm{V}$. Calker F. In silver. I782. Diameter I $3 / 4$ inches.

Fr. $100-$

466 Acknowledgment of the United States of America by the United Netherlands. "Nederland verklaard America Vry." Reverse: "De algemeene Wunsch I782". By J. M. Lageman. In silver. Diameter I $3 / 8$ inches. Fr. So -

467 Original sepia drawing for this medal. "V. H. fec." 8 vo.

Fr. $40-$

468 Sieges of Mahon and Gibraltar. "Sic Hostes Concordia Jungit Amicos. 17 87 ." In zinc. Diameter I 3/4 inches.

Fr. $20-$ 
469 "Franco-Americana Colonia Castorland 1796." Reverse: "Salve Magna Parens Frugum". In silver. Br Duv. (Duvivier). Diameter $11 / 4$ inches. F1. 45 -

470 "Union of Erie with the Atlantic." Reverse: "Erie Canal Comm. 4 July I8I7 Comp. 26 Oct. i825." C. C. Wright sc. 1826 . Presented by the City of New York". In silver. Diameter I 34 inches.

Fr. $90-$

47I Treaty of commerce with France. By Andrieu and Gayrand. In copper. Diameter 2 inches. (Loubat 53.)

Fr. 20 -

472 "Vincentius Comes Piccolomini de Aragonia." Reverse: "Californiae descriptae I836". In copper. Diameter 2 inches.

Fr. 12

473 Merchant's Exchange Wall Street, New York. In copper. About 1850 .

474 New York Crystal Palace, 1853. In white metal. Diameter I 3,4 inches.

Fr. 0 -

475 New York Crystal Palace, 1853. Fitzgibbon Daguerrotype Gallerie. Gilt bronze. 1)iameter I I 8 inches.

Fr. 4 -

476 Pennsylvania Volunteers, Gettysburg 1862. In copper.

Diameter I I's inches.

Fr. $8-$

477 The same. In white metal.

Fr. $8-$

478 In commemoration of the great central fair for the U. S. Sanitary commission held at Philadelphia, June 1864. In copper. Diameter 2 it 4 inches.

Fr. 15 -

479 “Massachusetts 1866." Reverse: “Lexington I775, Baltimore 186 I". In copper. Diameter I $1 / 8$ inches.

Fr. 4 -

4So "Alianza Americana de 1866." Reverse: Bombardment of a port. By Ch. Wiener. In copper. Diameter 3 inches.

Fr. $15-$

48 I "Zweites Schweizer Nationalfest in New York, 1873.

In copper. Diameter I $1 / 16$ inches.

Fr. 4 - 
482 "International Exhibition Philadelphia 1876. Awarded by U. S. Centennial Commission." In copper. Diameter 3 inches.

Fr. Iо -

483 Exposition internationale de Philadelphie en 1876. Participation de la France." In copper. Diameter 2 inches

Fr. 10 -

484 " Cathedral of St. Peter \& St. Paul. Philadelphia 1878." In white metal. Diameter I I/4 inches. Fr. 4 -

485 L. W. Lyons \& Co. Clothing goods, New Orleans. In white metal.

Fr. 3 -

486 The Old Round House, Le Roy. N. Y. Demolished I857. In copper. Diameter I 5/16 inches. Fr. 4 -

487 Magnetic Powder and Pills for insects and rats. 424 Broadway, New York. Gilt bronze. Diameter I I/S inches.

Fr. 3 -

488 "City Hall New York." Reverse: "Theodor Bollenhagen \& Co ". In copper.

Fr. 3 -

489 "Awarded by the Mechanics institute 187\%. Industrial Exhibition San Francisco." By A. Desmarest, New York. Diameter 3 inches.

Fr. $15-$

490 Monument association of the capture of Andre, Tarrytown, N. Y.1880. In copper.

Fr. 4 -

49I "Foreign Exhibition, Boston, Mass. 1883." In white metal.

Fr. 4 -

492 "Awarded by the worlds industrial and cotton centennial exposition." Reverse: "New Orleans, I 884-5". In copper. Diameter $27 / 8$ inches. Fr. Iо -

493 Ice Palace (New York) I 856. In white metal. Fr. 4 -

494 Two cities in one. New York and Brooklyn. I888. In white metal. Diameter I $3 / 8$ inches. Fr. 5 -

495 "Souvenir de la visite du Comte de Paris aux EtatsUnis, 1890." In white metal. Fr. 4 - 

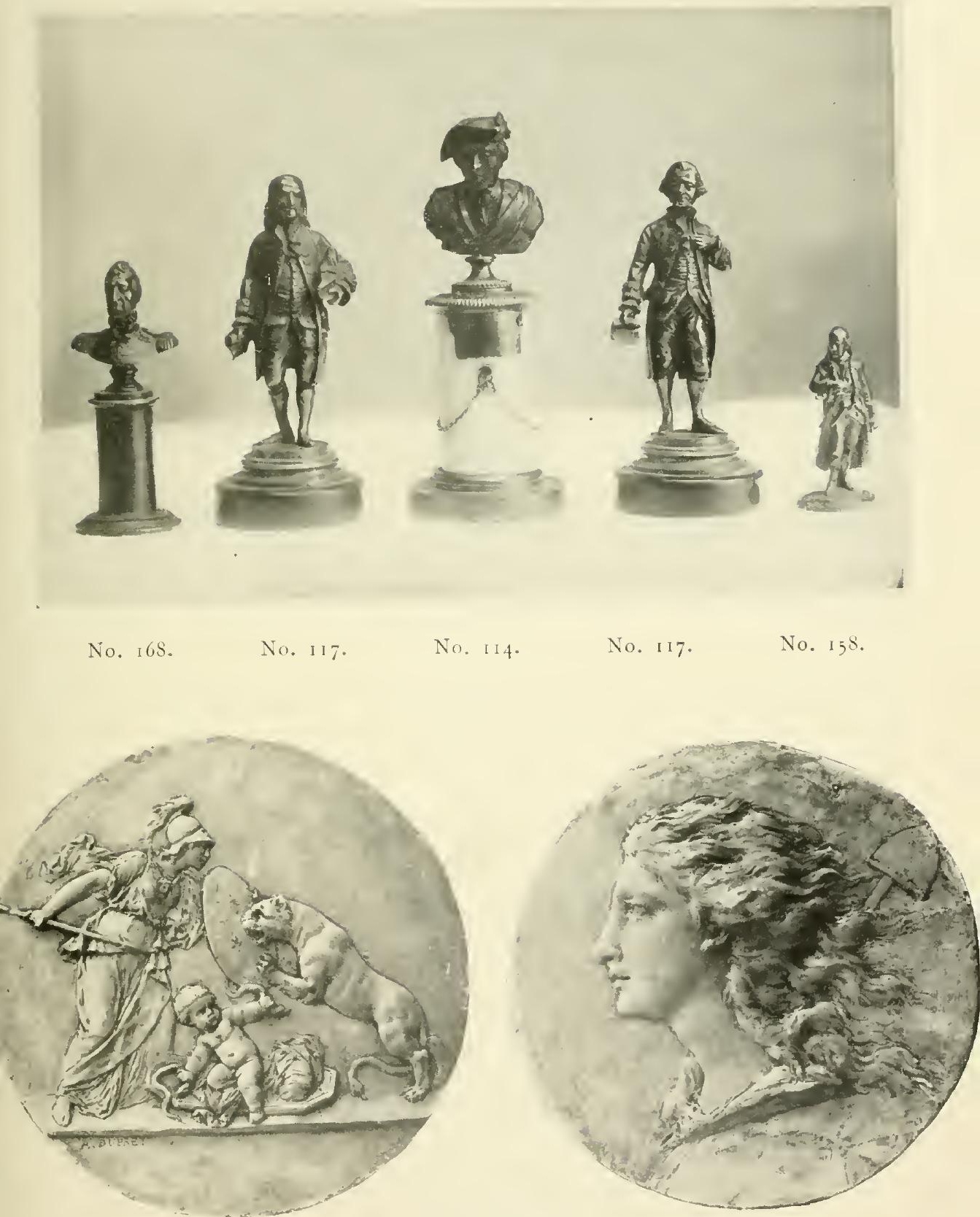

No. $4^{60}$. 


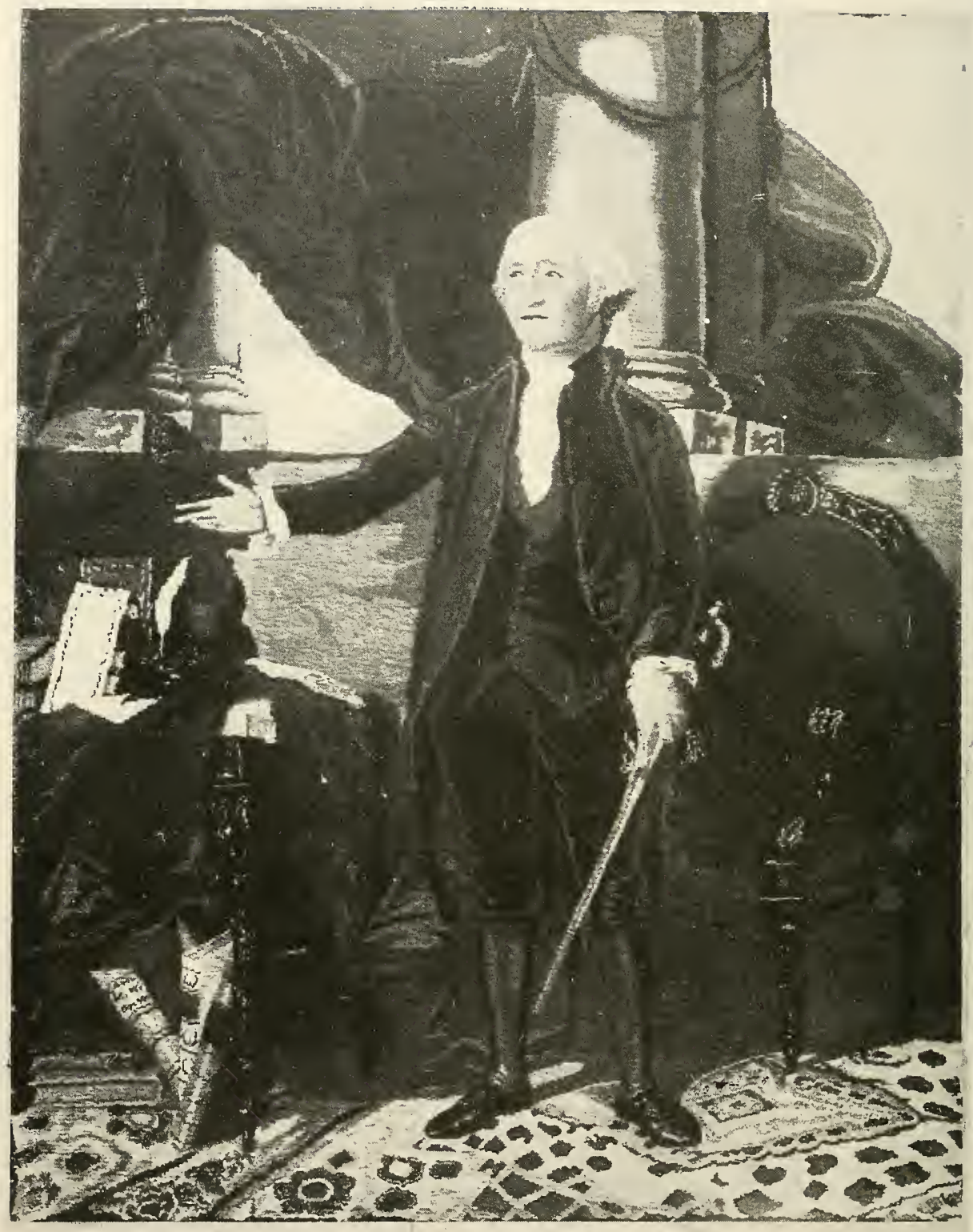

George WVashingtox.

See No. 324. 
496 Denver Colorado Masonic Temple, 1892. In white metal

497 Choicest clear Havanas. Reverse: E. T. Bermel Co. Chicago. In copper. Diameter $23 / 4$ inches. Fr. $5-$ 49S Real Fabrica da Honradez Habana. In white metal. Diameter $21 / 4$ inches. Fr. 5 -

499 World's Columbian Exposition, Chicago, 1893. Machinery Hall. Reverse: "G. Potter Yr. \& Co". In copper. Diameter $23 / 4$ inches.

Fr. 5 -

500 Anditorium Building Chicago, 1893. In copper. Diameter $23 / 4$ inches.

Fr. 5 - 


\section{INDEX OF NAMES}

Ackington (J. L.), 329 . Adams (John), 69, 88. Adams (J. Quincy), 88. Allston (Washington), 330. Amherst (Lord), 448 . André (Colonel), 490. Arnold (B.), 3.

Bailly (J.Sylvain), 265, 266 . Ball (Daniel), 332.

Bart (Jean), 33 .

Beaufort (Duc de), 33.

Beaussier (Captain), 49 .

Bell (John), 331.

Boscawen (Admiral), 447, $44^{8}$.

Bouillé (Marquisde), 13, I 4 .

Boyer (J. B.), I8o.

Bradstreet (Colonel), 448 .

Brown (John), 333.

Burke (Edmund), 73.

Byron (Lord), 38.

Cabot (Sebastian), 107.

Carroll of Carolton (Ch.), 70.

Cartier (Jacques), 107.

Catherine II of Russia, 453 .

Clay (Henry), 334-336.

Cleveland (Grover), 337.

Cody (S. E), 339 .

Columbus (Chr.), 48, 60, $105,175,181,340-342$.

Cook (Capt. James), 307 a.

Cooper (Fenimore), 90, ${ }_{1} 8_{2}, 183$.

Cornwallis (Lord), 306,307 .

Cortez (Ferd.) 106, I07, 343-345.

Crul (Capt. Wilh.), $34^{6}$.

Custine (Comte de), 1 I.

Decatur (Stephen), 87, 287 .

Deux-Ponts (Comte de), I 1 .

Dreux-Brézé (Ad miral), 33.

Duguay-Trouin, 33, 45.

Dumouriez, I01, 271 .

Duquesne (Abraham), 33.

Estaing (Comted'), 36, 51, $54,85,283$.

Forbes (General), 448 .
Franklin (Benjamin), 2, 4, I $8,27,28,31,42,51$, $54,83,88,91$, I $17,136-$ $164,184-2$ I 4, 272, 223 , $244^{-255}, 291,292,297^{-}$ $299,310,315,320,323$, $325,326,340-353,460$.

Frelinghuysen, 336 .

Garfield (James), 361 .

Gates (Horatio), 92, 354.

Gérard (Marshal), 272.

Grant (Ulysses S), 356.

Grasse (Comte de), 35.

Guichen (Comte de), 38 .

Hancock (John), 37 .

Hancock (Winfield S.), 357.

Hardy (Sir Charles), 93.

Harrison (Gen. Benj.), 359.

Harrison (General Will. Henry), 94-96, 358 .

Howard (John Eager), 362. Howe (Rich. Earl), 22, 448, 452.

Huggins (Capt. Benj.), 62. Hull (Isaac), 287.

Jackson (Gen. A.), 88, 300. Jay (John), 44.

Jefferson (Th.), 88, 223.

Jones (Comm. Jacob), 303.

Jones (John Paul), 284,365 .

Keppel (Admiral Lord), $44^{8}$.

Kosciusczko (Th.), 367 , 423.

La Fayette (Marquis de), I, 15, 2I, 29, 30, 47, $59,78,89,98-101,127$, 165-169, 215-219, 256$282,304,316,317,327$, $328,368-385,423$.

La Galissonnière, 33, I 76 .

La Roche St. André, 33.

Laval-Montmorency (Duc de), I I .

Lee (General), I78.

Lery (P.) U. S. Navy, 120.

L'Etanduere (Marquis de), 33.
Lincoln (Abr.), 4!, 170-1 74, $221,295,386-392$.

Livingston (Rob. R.) 460.

Louis XIV, 433-44I.

Louis XV, 441 .

Louis XVI, 53, 54, 91, 264, 285,328 .

Louis Philippe, 28I, 304, 379.

Mc. Clellan (George B.), 393,394 .

Madison, 88 .

Magelhaëns, 107 .

Mahé de la Bourdonnais, 25,33 .

Marie Antoinette (Queen), 266, 267.

Mirabeau, 265 .

Monroè (James), 88.

Montesquieu, 318.

Montyon, 320, 353 .

Morgan (Gen. Daniel), 395,396 .

Morris (Governor), 293.

Morse (Samuel), I02.

Mullen (Wm. J.) 397.

Napoléon I ${ }^{\text {er }}, 289$.

Necker, 265.

Ogle (Sir Chal.) 445.

Paez (José Ant.), 177.

Petion (Alex.), i 80.

Piccolomini (Count V.), 472.

Pichegru, Ior, 271.

Pintard (John), 399 .

Pizarro, 107.

Porter (Gen. Peter Buel), 400.

Preble (Capt.), 3 I8.

Raikes (Rob.), 401.

Reed (General), 2932 294.

Rochambeau (Comte de), $20,23,24,43,51,52,54$.

Rodney (Admiral), 402 .

Rousseau (J.-J.), 250-255, $325,326$.

St. Vincent (Earl), 403 .

Saunders (Admiral), 449 . 
Sauvage (F.), 179.

Scott (General Winfield), I 7 , 302, 303.

Soto (Hernando de), 107.

Stonewall (T. J. Jackson), 364 .

Suffren (Admiral), 34 .

Taylor (Ch.), 300.

Taylor (Zachary), 404 .

Tlumb (Gen. Tom), 405.

Truxtun (Capt. Thom), 406.
Valbelle, 33.

Van Buren, 97.

Vernon (Admiral), 442446.

Verplank (Gullan C ), 407.

Vespucci (Amerigo), I 07 .

Voltaire, $250-255,318,325$ 326.

Washington (George), 5$9,23,24,32,50,51,56$, $78,88,104,114-135,222-$ $237,235-243,289,201$,
$202,294,301,305,306$, $308,318,319,321,322$, $324,408-426$.

IV aslington (VVill. Aug.), 427.

Webster (Daniel), 430, 431.

West (Benjamin), 39.

IVest (Raphael), 79.

Wildey (Thomas), 432.

11 olfe (Gen. James), So-š, 449 .

\section{TOPOGRAPHICAL INDEX}

Austin, 398.

Antigua, 65 .

Bay St. Bermard, 26.

Boston, 408, 49I.

Brandywine, 375 .

Bristom hill, I 3 .

Brooklyn, N. Y., 4)4.

California, 472 .

Callao, 87 .

Canada, 80-82, 111,112 , I 76 .

Cape Breton, 447 .

Carthagena, 433, 439, 443446.

Castorland, 469 .

Cayenne, 436 .

Cedar Mountain, 364 .

Charlestown, Mass., 102.

Charlestown, Va., 333.

Chicago, 499, 500 .

Chicopée, 223.

Chippewa, 400.

Cowpens (The), 3(12, 395. 427 .

Curaçao, $34^{6}$.

Denver, Col., $49^{6 .}$

Erie, 400, 470.

Florida, 107.

Fort Erie, 57.

Fort Oswego, 57.

Front-Royal, 364 .

Jettysburg, $47^{6}, 477$.

Gold Harbour, 364 .
Grand Rapids, Mich., 332 .

Grenada (Island of), 85 .

Guadaloupe, 44 .

Hayti, 5S, ISo.

Halifax, 111 , I 2 .

Harrisonburg, 364 .

Havana, 497, 498.

Ile Royale; 49.

Kernstown, ;64.

Le Roy, N. T. 480.

Lexington, 12.

Leyden, Mass., 223.

Lima, $63, S_{7}$.

Long Beach, 76 .

Louisbourg, $447,44^{8}$.

Louisiana, 26.

Louisville, Ohio, 75.

Malvern Hill, 364.

Marietta, Ohio, 74 .

Martinique, $38,64,100$, 434 .

Maryland, 7 .

Massachusetts, 479 .

Mechanicsville, 364 .

Middletown, 364 .

Mt. Vernon, 56.

Newbury, N. I., 223.

New Jersey, 394.

New Orleans, $472,485$.

New York city, 54, 61, 93, $307,399,401,431,473-$ $75,481,487,488,493$, 494 .
Niagara Falls, 57, 400 .

Nova Scotia, 4\%, 111.112.

Panama, 87 .

Pensylvania, 476,477 .

Peru, 63.

Philadelphia, 6, 10, 62, $422,432,450,47^{5}, 452$, $4^{S_{3}}, 4^{S_{4}}$.

Port-Republic, 364 .

Porto-Bello, 442.

Québec. So-82, 4;8, 449 .

Quito, 63 .

Rhode Island, 452.

San Blas, $S_{7}$.

San Francisco, 480 .

St. Christopher (Island of), 435 .

St. Domingue, (Hayti), 58.

Sandy Hill, N. Y. 46 .

Saratoga, 354, 454-461.

Savannah, 66.

Springfield, Pa., 70-\$2.

Strasburg, 364.

Tarrytown, N. Y., 490.

Texas, 339, 39 s.

Tobago, 14, 437 .

Torrington, Conn ., 333.

Valparaiso, 87 .

Venezuela, 177 .

White Oak Swamp, 364.

Winchester, 364 .

Yorktown, 11, 20, 23, 24, 306, 454-401. 


\section{INDEX OF PAINTERS, DRAUGHTSMEN SCULPTORS AND ENGRAVERS}

Adam (Victor), ז.

Armand Dumaresq, 3-I4. Aubry (L. Fr.), 2.

Auvrest, I 5 .

Baali (A. van), 453.

Barbedienne, 16 I.

Barré, 353.

Baugean, 17 .

Bernard, is.

Blot (E.), I 79 .

Bolen, 430.

Bovi (Hugues), 388.

Brown (Henry Kirke), 223.

Brown (John Lewis), 20.

Canova, 130, 149.

Caqué, 364 .

Caunois, 380 .

Chardigny, I62.

Clary, 21.

Collas (A.), 135.

Collet (John), 22.

Couder (L.-C.-A.), 23 .

Danloux (P.), 25.

David d'Angers, I $S_{3}, 216$, 2 I $7,220$.

Debarz (A.), 26.

Desmarest (A.), 489 .

Duplessis (J.-S.), $28,247$.

Duplessis-Bertaux, 29 .

Dupré (Aug.) 225, 245,32 I, $347-35 \mathrm{I}, 365$. 395, 454461 .

Durand, 340-344, 352, 367, 420.

Du Vivier (Jean), 441 .
Du Vivier (B.), 362, 373, $408,427,469$.

Eccleston (D.), 4 I 9 .

Etner (S.), 30.

Fiirst, 400 .

Gatteaux (N.), 354 .

Gerard ( $M^{1 l e}$ Narguerite), $3 \mathrm{I}$.

Girardet (Edouard), 32.

Godel, 352.

Graincourt (A.-V.-B.), 33.

Gribelin (E.-A.), 34 .

Gruyère (H.), I76.

Guillemin (Emile), I72.

Holzhey (J.-G.), $46_{3}$.

Houdon (J.-A.), i 8,136 , I 37, I 38, I 39 .

Janinet, 250,264 .

Jelgerhuis (Jean), 35 .

Juillet $\left(\mathrm{I}^{1 \mathrm{li}}\right), 257$.

Lacour (Pierre), 36.

Lagemann (I. M.), 466.

L.e Barbier aîné (J.-J.-Fr.), 37.

Le Chevalier (J.-B.), 38 .

Leslie (Ch. R.), 39.

Lienard, 360.

Logat, 423.

Maney (G.), 410.

Magniadas (Franky), 41, $39 \mathrm{~L}$.

Marchand ( $M^{\circ}$ Cécile), 289.

Martinet, 42 .

Massard (L.), 43-45.

Mauger (J.), 433, 435-440.
Milbert (J.-G.), ${ }_{46}$.

Horel fils, 239 .

Nini (J.-B.), 194, 203-212.

Oleszezynski (W.), 385.

Osmond (D.), 170.

Ozanne (N.-M.), 48, 49.

Pallière (Etienne), 50-54.

Peale (R.), зог.

Peiron (G.), 153.

Pfeiffer, 171 .

Pilkington (Rob.), 57.

Pine (Rob.-Edge), 56.

Potier, 58.

Quenedey (E.), 59, 259 .

Rither, 30 .

Robert Fleury, 60.

Rogers (Nathaniel), 6I.

Roux (Antoine), 62.

Salas (Ramos), 63.

Sauvage, 254 .

Serres (D.), 64-68.

Stuart (Gilbert), 69-7 I, 240 , 324.

Trentanove (R), 133 .

Vivier, 421 .

Warin (J.-B.), 74-77.

Wedgwood, 195, $231,232$.

Weiss (J.), 78 .

West (Benjamin), 79-84.

Westwood, 4i 7 .

Wiener (Ch.), 480.

Wille (Joh. G.), 85 .

Winden (J.), 333.

Wood (Ch.), $\mathrm{S}_{7}$.

Wright (C.-C.), 330, $47^{\circ}$. 


\section{GENERAL INDEX}

Amazon, the English frigate, 64,65 .

American Eagle, the, 312 , 313.

American Emblems, 9, 18, $31,50-54,95$, I15, 242, $243,286,311-314,318$, $319,323,453-467$.

American Stars, the, 3 II.

Athalante, the French Frigate, 108.

Bonbonnières, 238-290.

Brill, the Dutch frigate, 67 .

Bookseller, 329.

Calligraphical drawings, $15, \mathrm{t} 8,100$.

Canals, 470.

Carnation, - the English brick, 17 .

Castor, the Dutch frigate, 67 .

Cincinnatus, Decoration of, 9 .

Civil War, 4I, I70-I74, I $78,221,295,364,386-$ 392,476 .

Clocks, 296.

Comet, the, English frigate, 66.

Constitution, the U.S. frigate, 288 .

Crescent, the English fri* gate, 67.

Discovery of America, 105, $181,340-342$.

Dutch officer in the Revolutionary war 346 .

Dwarf 405.

Electricity, $42,83,84,147$.

Enamels, $291-295$.

English officers in the Revolutionary war, 22, 93 , $306,402,403$.

Exhibitions, 442, 474, 475, $482,483,489,491,49^{2}$, 499 .

Flora, the, English frigate, 67.

French officers in the Revolutionary war, I I, 20, $24,34,35,36,43,283$ and La Fayette, (see index of names).

Freemasonry, 322, 496.
Independence, American, proclamation of, $\mathbf{I O}$.

Independence, American, recognized by France and Holland, 51, 463-467.

Independence Hall, 450

Indians, 77 .

Inventions, $42,8_{3}, 8_{4}, 147$, I 79 .

Greenwich, the, English frigate, 66.

Guerrière, the, English frigate, 288 .

Halifax, the, Canadian vessel, 112.

Heros, the, French frigate, 49.

Kaskaskias Indians, 77 .

Keppel, the, English frigate, 66.

Languedoc, the, Count Estaing's flag ship, 36 .

Liberty Bell, 450.

Lightning, Franklin's in. vention, $42,83,147$.

Lovely Mathilda, of Philadelphia, the vessel, 62 .

Macedonian, the, English, afterwards, U. S. frigate, 87,287 .

Marengo, Capture of the frigate, 17 .

Miniature-painting, 2, 2I, $29,61,91$.

Medals, 34, 41, 329-500.

Medical, 478 .

Napoleonic wars, 289 .

Naval battles, I $7,38,4 \delta$, $49,64-68,108,110,287$, $433-449,452$.

Naval commanders, 23, 25, $33,35,45,220,283,284$, 303,307 a , 318, 346, 355, $402,403,406$.

Navigators, 48, 60, 105107 , $175,181,307$ a, 340-345.

New York Historical Society, 399 .

Northingham, the English frigate, 49 .

Penmanship, I6, I 8, 100.

Polish officer in the Revolutionary war, 367 .
Phoenix, the, English fri gate, 66r.

Physicist, see Franklin, (index of names).

Presidents of U.S.A., seeindex of names, (Washington, J. Adams, Jefferson, Madison, Monroe, J. Q. Adams, Jackson, Van Buren, Harrison, Taylor, Lincoln, Grant, Garfield, Cleveland, Benj. Harrison). President, the, U. S. frigate, 17.

Printer, see Franklin, (index of names).

Quakers, 39.

Revolutionary war, $7,8,9$, II, $12,13,14,20,23,24$, $3^{8}, 49,53,54,85,306$, $307,354,362,375,408$, $427,452-467,490$.

Sanitary commission held at Philadelphia, 478 .

Santa Catharina, the Spanish frigate, 108.

Serew - propellers, invention of, I 79.

Sèvres medallions, 196-202 .

Shawanoca Indians, 77 .

Shipping, 62, $8_{7}, 112,179$, 470.

Slavery and Slave trade, 58, I09, $171,333,386-392$.

Snuff boxes, $238-290$.

Sugar-cane, culture of, 58 .

Tapestry, 324 .

Telegraph, 102.

Terra-Cotta work, I 8,144 , $153,170,176,179,203-$ 206,211 .

Tobacco, 334-336, 497, 498 .

United States, the frigate, 287.

Vengeance, the French frigate, 406 .

Vigilant, the, English frigate, 66 .

War of $1812,17,178,287$ $289,302,303,400,406$.

Watches, 297 .

Wedgwood medallions, $195,231,232$. 


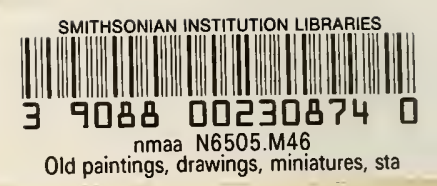

FRAZIER - SOYE $=$ I M PR I MEUR 153-155-157, Rue Montmartre $=P$ A R I S $=$ 